\title{
Electron microscopy of phagocytosis in syphilis and yaws
}

\author{
N. M. OVČINNIKOV AND V. V. DELEKTORSKIJ \\ Department of Microbiology, Central Institute of the Ministry of Health of the USSR for Research on Skin \\ and Venereal Diseases
}

In view of the great importance of phagocytosis in protecting the body against infection and in producing antibodies, the authors paid particular attention to phagocytosis in their electron microscope studies of tissues obtained from hard chancres in rabbits with syphilis and from testicular membranes in rabbits with yaws.

The nature of the phagocytosis by particular cells is described, as is the fate of the micro-organisms thus trapped.

Our previous papers (Ovčinnikov and Delektorskij, $1969,1970)$ reported on the interrelationship between treponemes and cellular elements. This paper represents a continuation of these studies.

Phagocytosis is one of the most important factors in the body's defences against infection. According to the definition of the founder of the phagocytic theory, Mečnikov (1884), 'the human and animal organism uses phagocytosis for the resorption of tissue elements, blood, and exudates, and also for the destruction of microbes, including those which produce infectious diseases'.

Phagocytosis should not be looked upon as the culmination of the struggle between microbe and macro-organism. It represents the beginning of that struggle, the nature of which depends on the immunological activity of the body and on the condition of the Treponema pallidum organism (its viability, the production of L-forms, encystment, etc.).

In essence all our drugs prove efficient only when they interact with the protective mechanisms of the host. The subsequent work of destruction is carried out by the cells of the body. In the initial stages of an infection, phagocytosis plays an extremely important role in the transmission of antigenic information and in bringing immunological processes into play against the infection.

As the syphilitic process develops, so the role of phagocytosis in the body's fight against the infection becomes more important, making a study of this

Received for publication December 12, 1971

This work was done with financial support from the World Health Organization phenomenon extremely valuable. It is clear that the fate of the micro-organism will differ according to the cell which carries out the phagocytosis.

As a result of the possibilities offered nowadays by electron microscopy of ultrathin sections of various materials, it has become possible to investigate this phenomenon more thoroughly.

The method of investigation has been described in previous papers and is essentially unchanged.

According to various authors, diffuse infiltration by mononuclears, mainly lymphocytes and plasma cells, is encountered in syphilis. In the lesions caused by yaws strains, the reaction is similar in nature but considerably less marked.

In all yaws lesions myxomatous changes were also found but were not so intense as in syphilis. 'To sum up', wrote Turner and Hollander (1957), 'the histological features of the localized and generalized lesions of framboesia in rabbits present striking resemblances to those of syphilis in the same animals'. They inclined to the view that the ability of the various treponemes to produce hyaluronic acid varied and that this property might serve as a criterion for differentiating between strains.

Mečnikov (1923) also paid special attention to the study of phagocytosis in spirochaetal diseases. In particular, he wrote that, because in relapsing fever the spirochaetes disappeared from the blood after a very short time and no phagocytosis could be detected in man during this process, the pattern of relapsing fever was for some time considered to be a serious objection to the phagocytosis theory. However, after several monkeys in various stages of illness and convalescence had been killed and examined, he found that the disappearance of the spirochaetes was caused by phagocytes with polymorphous nuclei or microphages.

During an attack, the bulk of the spirochaetes move freely in the blood and only a few of them are captured by the blood microphages. More vigorous phagocytosis occurs in the spleen. It is only in the stage preceding the temperature crisis that the capture of spirochaetes by phagocytes takes place on a 
considerable scale. The destruction of the relapsing fever agents inside phagocytes can thus be demonstrated, but the death of these bacteria in the blood plasma has never been observed. 'When the disappearance of spirochaetes from the blood at the crisis in both man and monkeys is being observed it can be seen that they are highly mobile and morphologically unchanged'.

'Phagocytosis, which plays such an important role in recovery from relapsing fever, is also a good weapon against chronic spirochaetosis. Many research workers have noted widespread phagocytosis with spirochaetes (Ehrmann, 1906; Gierke, 1906, 1907; Levaditi, 1906; Levaditi and Roché, 1907). It is specifically the microphages which play the main part. This provides a simple explanation for the fact noted long ago that in syphilomata there is always a considerable predominance of mononuclears' (Mečnikov, 1951).

On the other hand, a number of authors have never observed phagocytosis in syphilis. Under dark-field examination, phagocytosis of Treponema pallidum is very difficult to see and, because of the small size of the treponeme, it is impossible to observe the fine relationships between body cells and $T$. pallidum. Electron microscopy has opened up wide prospects for the study of this phenomenon.

However, before going on to describe phagocytosis in syphilis and yaws, it must be pointed out that the basic postulates of Mečnikov remain true to this day. In this respect we agree with Ado (1961) that Mečnikov's theory of phagocytosis has withstood the test of time and that phagocytosis is one of the mechanisms by which man and animals obtain natural or acquired immunity to infectious diseases. 'Phagocytes have proved to be capable of protecting the infected organism from pathogenic microbes both by absorbing, destroying, and digesting them direct and by bringing into play the basic mechanism of humoral immunity-antibody formation' (Ado, 1961).

In this paper we shall not touch on debatable or already settled problems, such as the effect of the medium on phagocytosis or theories of the phagocytic process, e.g. physical, neuro-endocrine regulation, etc. Although this is directly connected with phagocytosis it is common to all infections, and the problem is either already partly solved or is highly debatable.

Mečnikov (1884) himself considered it is impossible to reduce biological features to physico-chemical terms. However, our main reason for not dealing with this matter is that a journal article is not long enough to discuss these and many other aspects of phagocytosis.

When studying phagocytosis in various infections (gonorrhoea, staphylococcal diseases, syphilis, and yaws), we note that the cellular reaction differs in these different infections. Whereas in acute infections (gonorrhoea, pyodermia) the main cells involved are neutrophils, in syphilis and yaws they are lymphocytes, monocytes, plasma cells, and microphages.

It should also be noted that the cytological pattern will depend on duration of the process and the nature of its course. It must be understood that there is no appreciable difference in phagocytosis between $T$. pallidum and $T$. pertenue. For that reason we shall consider these two infections together.

According to Mečnikov, phagocytosis consists of four consecutive stages:

(1) The approach of the phagocyte to the substance which is to undergo phagocytosis;

(2) The attraction stage;

(3) Absorption;

(4) Digestion.

(1) The approach stage can be seen clearly in Fig. 1. The cell is moving by means of its pseudopodia (Ps). The treponeme, which has undergone no visible changes, is outside the cell but surrounded by an amorphous mass.

(2) The attraction stage is demonstrated by Fig. 2 . The treponeme is close to the membrane of the cell, in which invagination has already begun. The cell itself is undergoing division.

(3) Absorption occurs in different ways:

(a) Invagination occurs at the point of attraction (Fig. 3) and gradually goes deeper (Fig. 4). The object undergoing phagocytosis is drawn ever deeper and the cytoplasmic membrane joins together over the treponeme.

The treponeme is then inside the cell and surrounded by a membrane (Figs 5 and 6). The captured treponeme lies mainly parallel to the outer membrane (Figs 5 and 7). Sometimes the invagination leads to the formation of a deep canal, the walls of which stretch, without closing up, along the whole length of the cell.

(b) The cell puts out pseudopodia, sometimes in very large numbers, with which it captures the treponeme. The ends of the pseudopodia fuse and the treponeme is surrounded by a ring consisting of the cytoplasmic membrane with a narrow band of hyaloplasm (Fig. 8). The treponeme is then drawn deeply into the body of the cell (Figs 9 and 10). 

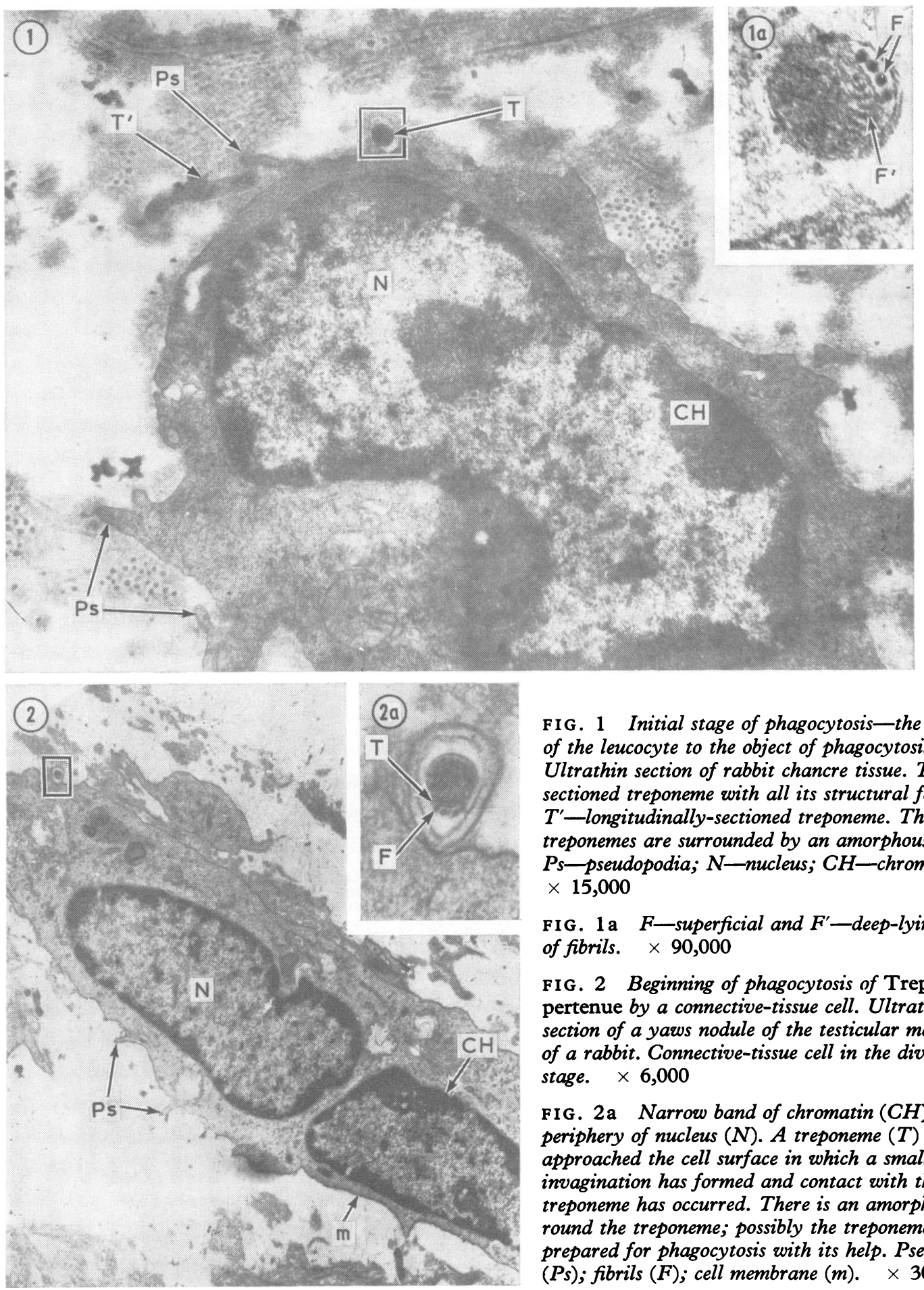

FIG. 1 Initial stage of phagocytosis-the approach of the leucocyte to the object of phagocytosis. Ultrathin section of rabbit chancre tissue. T-crosssectioned treponeme with all its structural features. $T^{\prime}$-longitudinally-sectioned treponeme. The treponemes are surrounded by an amorphous mass. $\mathrm{Ps}$-pseudopodia; $\mathrm{N}$-nucleus; $\mathrm{CH}$-chromatin. $\times 15,000$

FIG. 1 a $F$-superficial and $F^{\prime}$-deep-lying bundles of fibrils. $\times 90,000$

FIG. 2 Beginning of phagocytosis of Treponema pertenue by a connective-tissue cell. Ultrathin section of a yaws nodule of the testicular membrane of a rabbit. Connective-tissue cell in the division stage. $\times 6,000$

FIG. 2a Narrow band of chromatin $(\mathrm{CH})$ on periphery of nucleus $(N)$. A treponeme $(T)$ has approached the cell surface in which a small invagination has formed and contact with the treponeme has occurred. There is an amorphous mass round the treponeme; possibly the treponeme is being prepared for phagocytosis with its help. Pseudopodia $(P s)$; fibrils $(F)$; cell membrane $(m) . \quad \times 30,000$ 


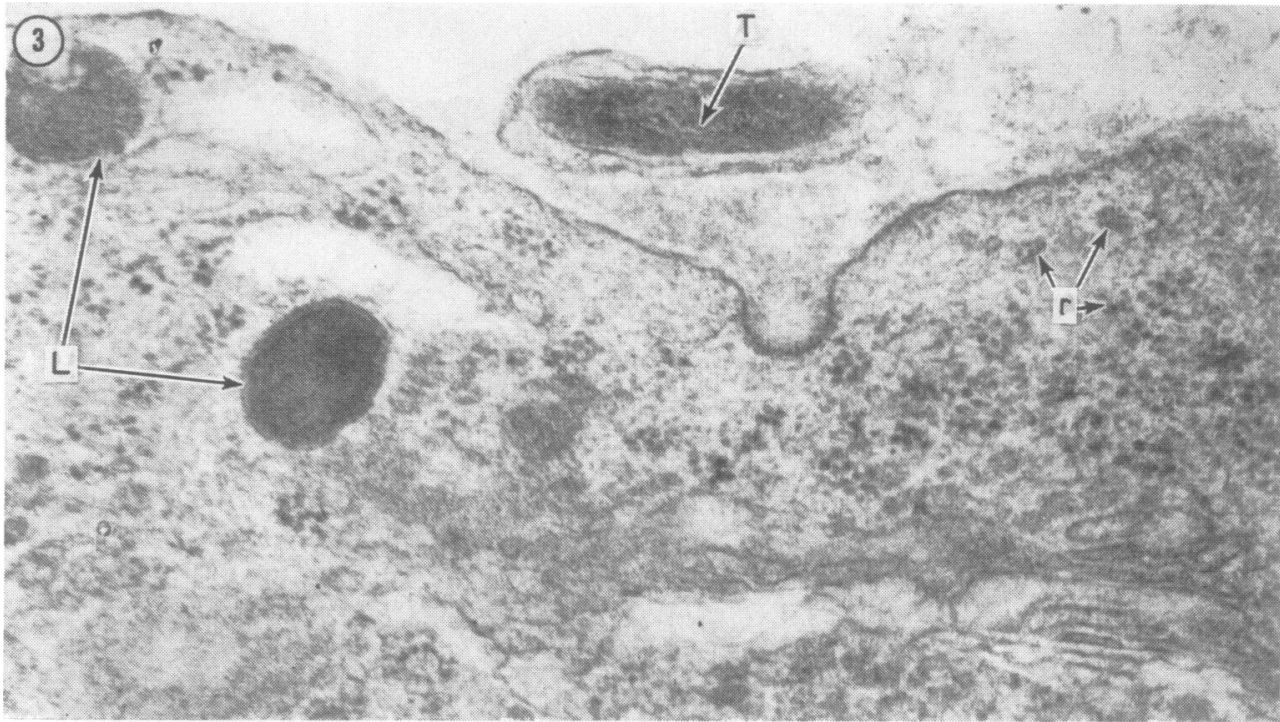

FIG. 3 Beginning of phagocytosis of Treponema pallidum by a macrophage. Ultrathin section of rabbit hard-chancre tissue. Invagination is clearly visible. The treponeme $(T)$ is surrounded by an amorphous mass and has undergone partial change. Ribosomes $(r)$; lysosomes $(L) . \quad \times 38,000$

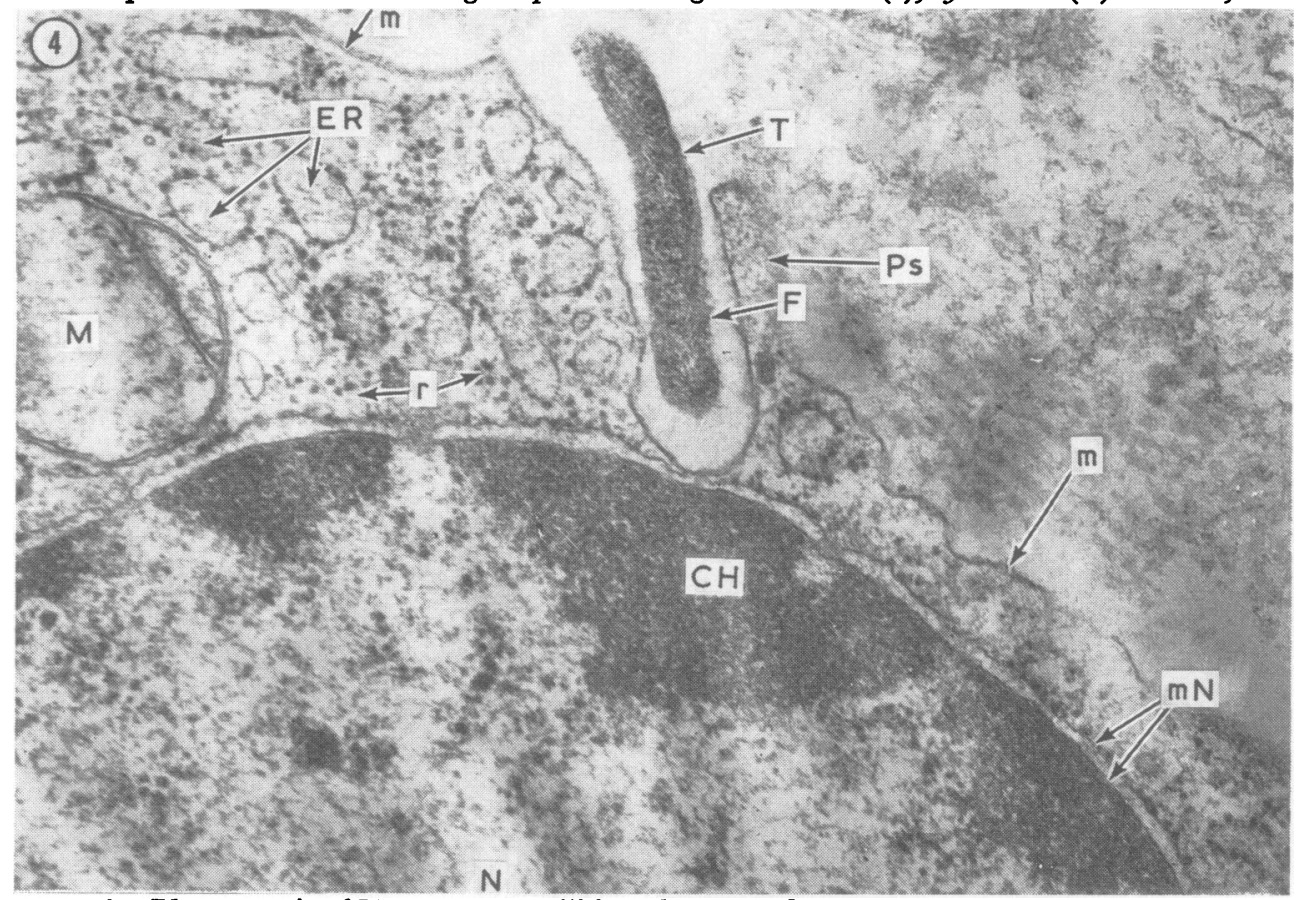

FIG. 4 Phagocytosis of Treponema pallidum by a mesolymphocyte. Ultrathin section of rabbit hard-chancre tissue. The invagination reaches the outer nuclear membrane. The treponeme $(T)$ has undergone partial change and fibrils are visible $(F)$. There are a few large ribosomes $(r)$, endoplasmic reticulum $(E R)$, mitochondria $(M)$, pseudopodia $(P s)$, and clearly visible cell membranes $(m)$ and nuclear membrane $(m N)$. CH-chromatin. $\quad \times 30,000$ 


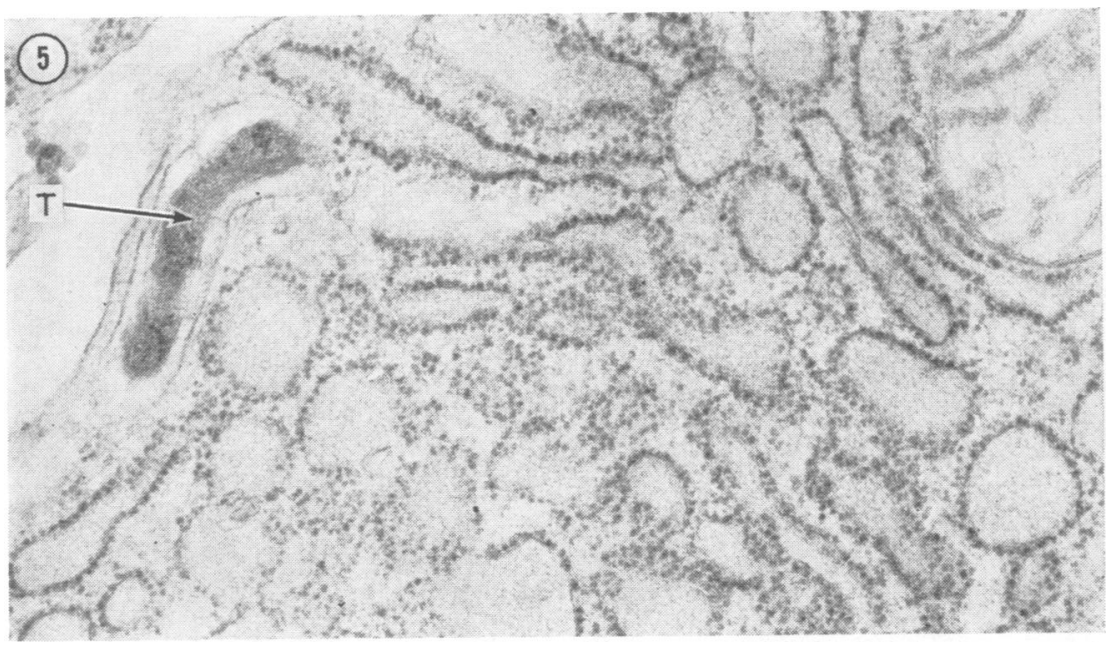

FIG. 5 Phagocytosis of Treponema pertenue by $a$ plasma cell. Ultrathin section of a yaws nodule of the testicular membrane of a rabbit. The treponeme (T) lies parallel to the outer cell membrane, is partly lysed, and has no outer wall. The walls of the phagosome are clearly visible. $\quad \times 30,000$

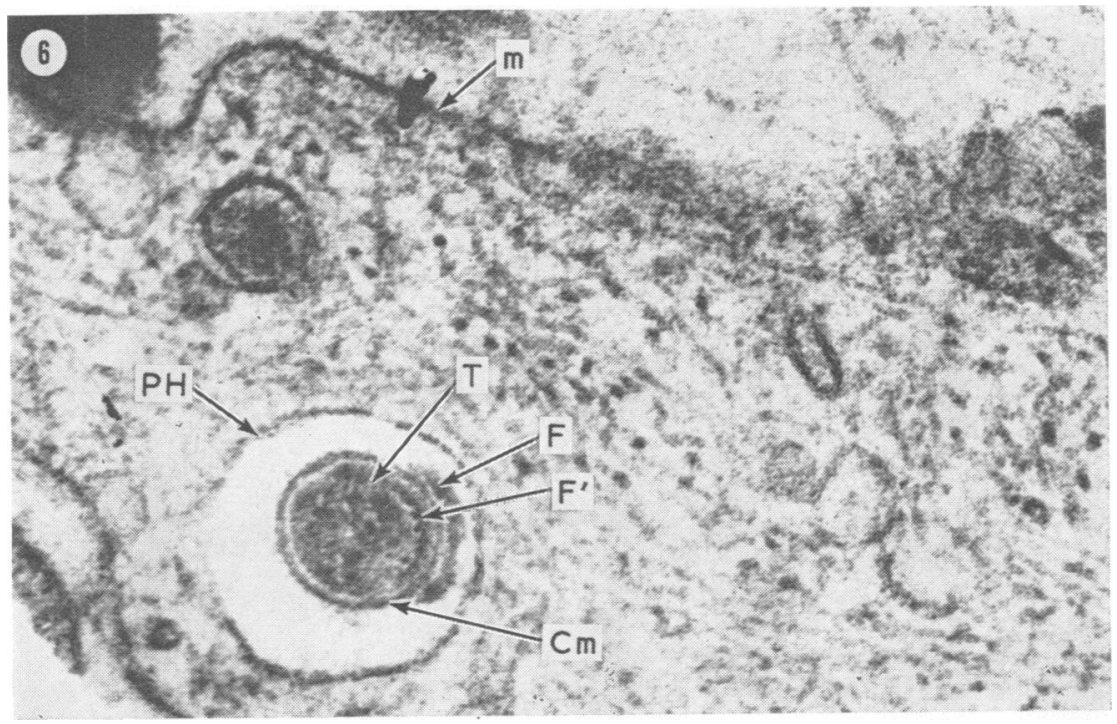

FIG. 6 Phagocytosis of Treponema pertenue by $a$ fibroblast. Ultrathin section of a yaws nodule of rabbit testicular membrane. $A$ treponeme $(T)$ inside a phagosome (PH). The superficial $(F)$ and deeplying $\left(F^{\prime}\right)$ bundles of fibrils, the cytoplasmic membrane $(\mathrm{Cm})$, and the cell membrane (m) are clearly outlined. $\times 75,000$

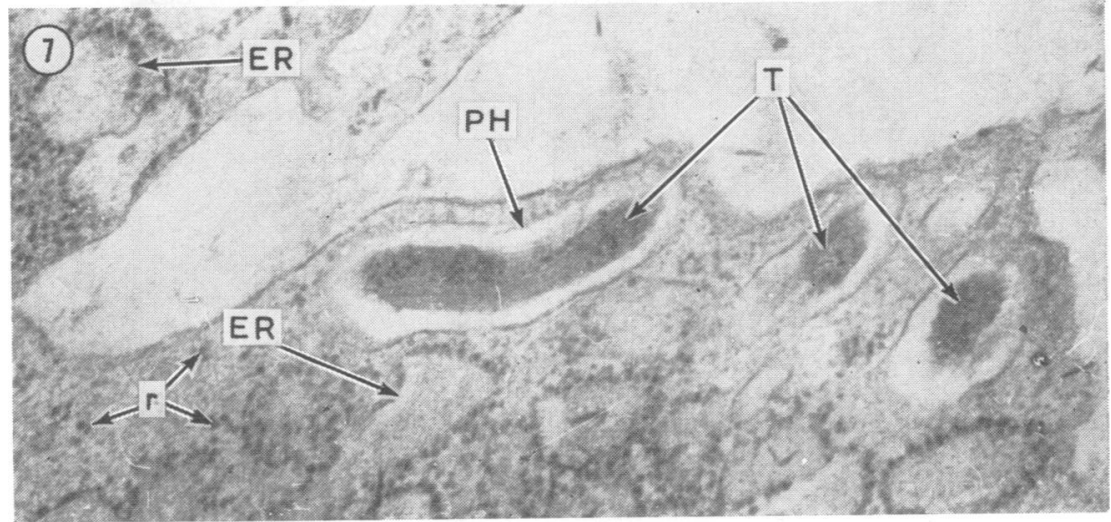

FIG. 7 Phagocytosis of Treponema pertenue by $a$ plasma cell. Ultrathin section of a yaws nodule of rabbit testicular membrane. $A$ treponeme ( $T$ ) lies parallel to the outer cell membrane. The phagosomal canal $(P H)$ is long and the treponeme gives the impression of being three separate organisms, although it is apparently only one. ER-endoplasmic reticulum; $r$-ribosomes. $\times 30,000$ 


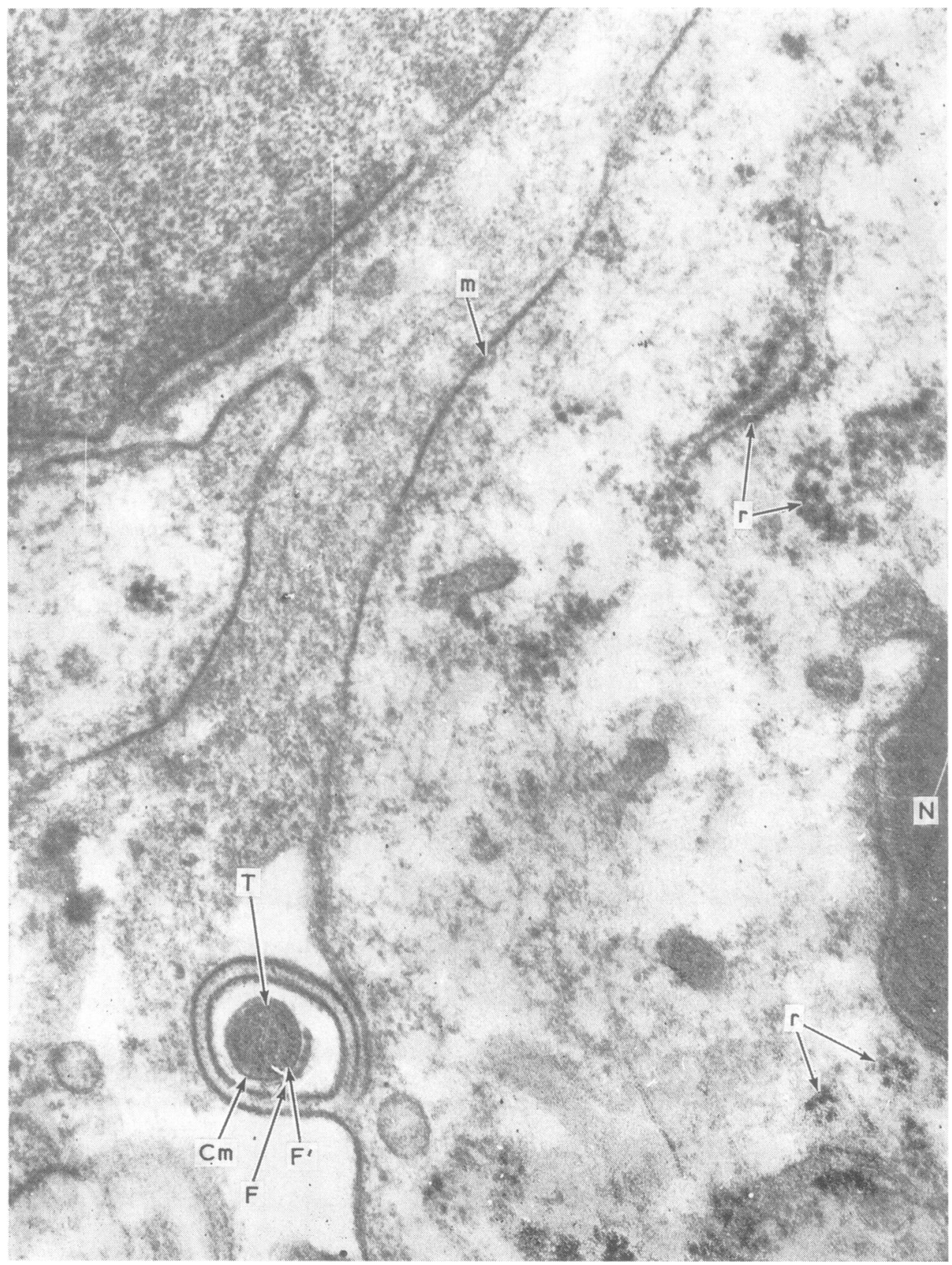

FIG. 8 Phagocytosis of Treponema pallidum. Ultrathin section of rabbit hard-chancre tissue 45 days after infection. The treponeme $(T)$ is surrounded by a cell membrane with a narrow rim of cytoplasm. The structure of the treponeme has undergone some changes, although they are inconsiderable as yet. The superficial $(F)$ and deep-lying $\left(F^{\prime}\right)$ bundles of fibrils and the cytoplasmic membrane $(\mathrm{Cm})$ are clearly visible. Nucleus $(N)$; ribosomes $(r)$; cell membrane $(m) . \times 45,000$ 


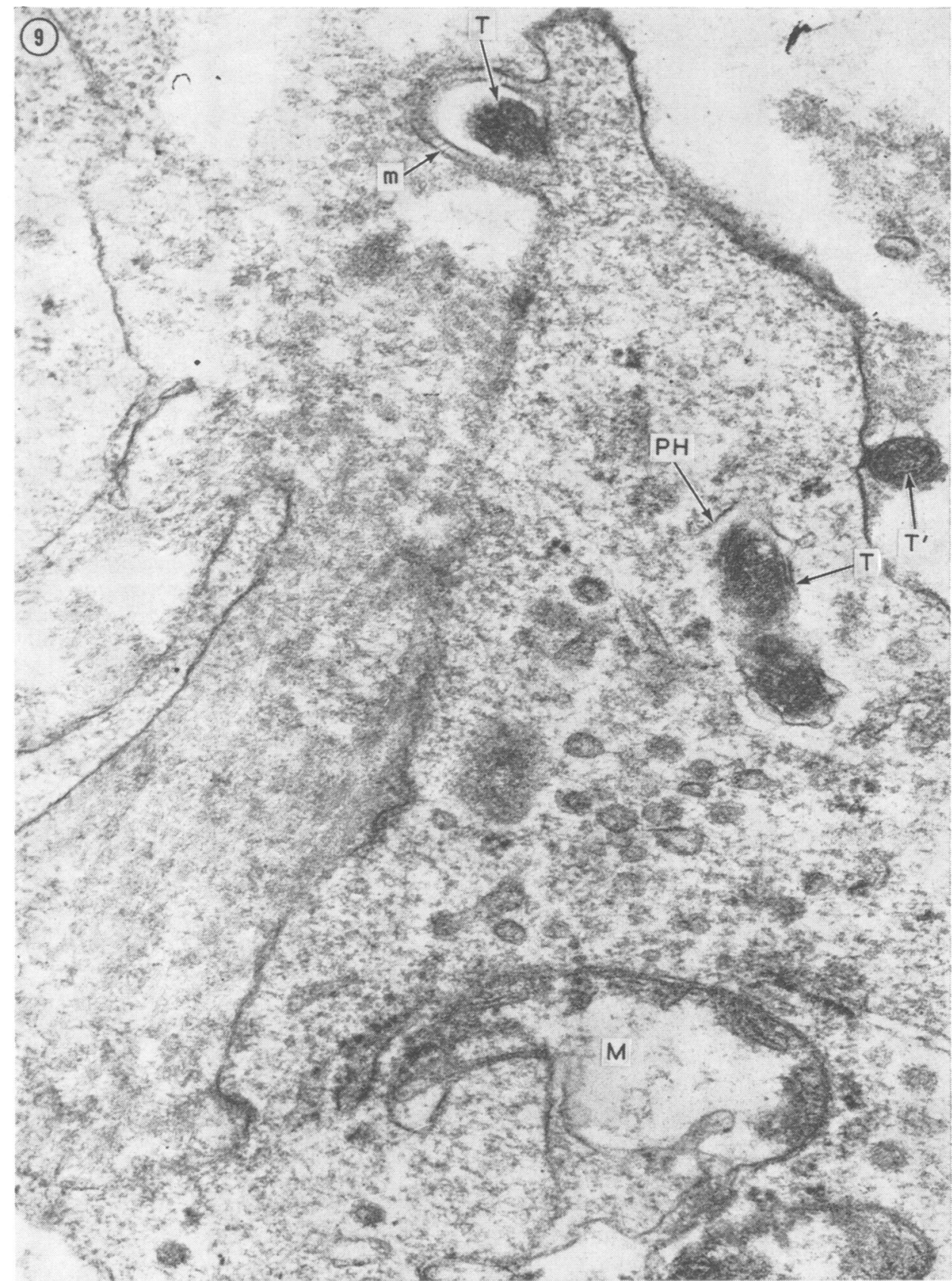

FIG. 9 Phagocytosis of Treponema pallidum organisms by a macrophage. Ultrathin section of rabbit hardchancre tissue 42 days after infection. The treponemes $(T)$ are partly lysed and have been captured by the lamellar processes of the plasma membrane $(m)$. In the intracellular treponemes at a deeper level the walls of the phagosomal canal $(P H)$ can be seen. The treponeme itself is undergoing lysis. The cristae of the mitochondria $(M)$ are halfdestroyed and the walls are also partially destroyed. The treponeme outside the cell $\left(T^{\prime}\right)$ but already touching these membranes has kept all its structural features. $\quad \times 38,000$ 


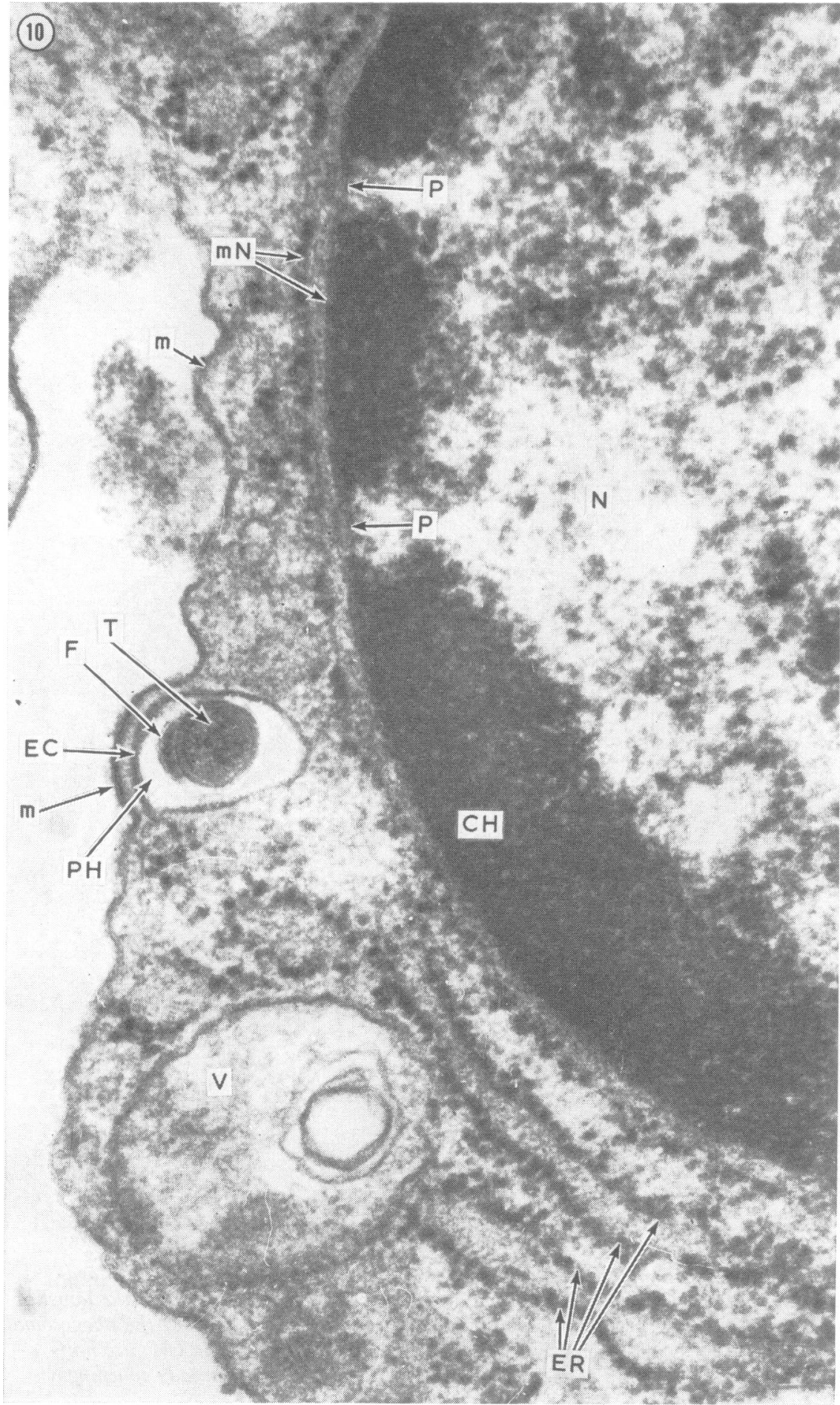

FIG. 10 Phagocytosis of Treponema pallidum by a plasma cell. Ultrathin section of rabbit hard-chancre tissue 47 days after infection. The phagocytosed treponeme (T) has a clear-cut structure. The fibrils $(F)$ can be seen. There is a phagosome $(\mathrm{PH})$ separated from the plasma membrane ( $m$ ) by a narrow band of ectoplasm (EC). There is a large vacuole $(V)$ with a residual body. The cell contents consist of marked endoplasmic reticulum (ER), a nucleus $(N)$ with chromatin $(\mathrm{CH})$, and outer and inner nuclear membranes $(m N)$ and pores $(P) . \quad \times 70,000$ 
We shall not touch on the physicochemical processes which determine this phenomenon. A considerable number of special investigations have been carried out in regard to it. Mečnikov ascribed it to positive chemotaxis.

(4) The last stage, digestion, does not always take place. Sometimes the phagocytosed microbe or particle is simply isolated and sometimes even multiplication takes place. This further progress of phagocytosis depends above all on the phagocytosing cell and the object undergoing phagocytosis. The beginning of phagocytosis by a monocyte (Fig. 11), a mesolymphocyte (Fig. 12), and a plasma cell (Fig. 13) is clearly visible in the electron micrographs.
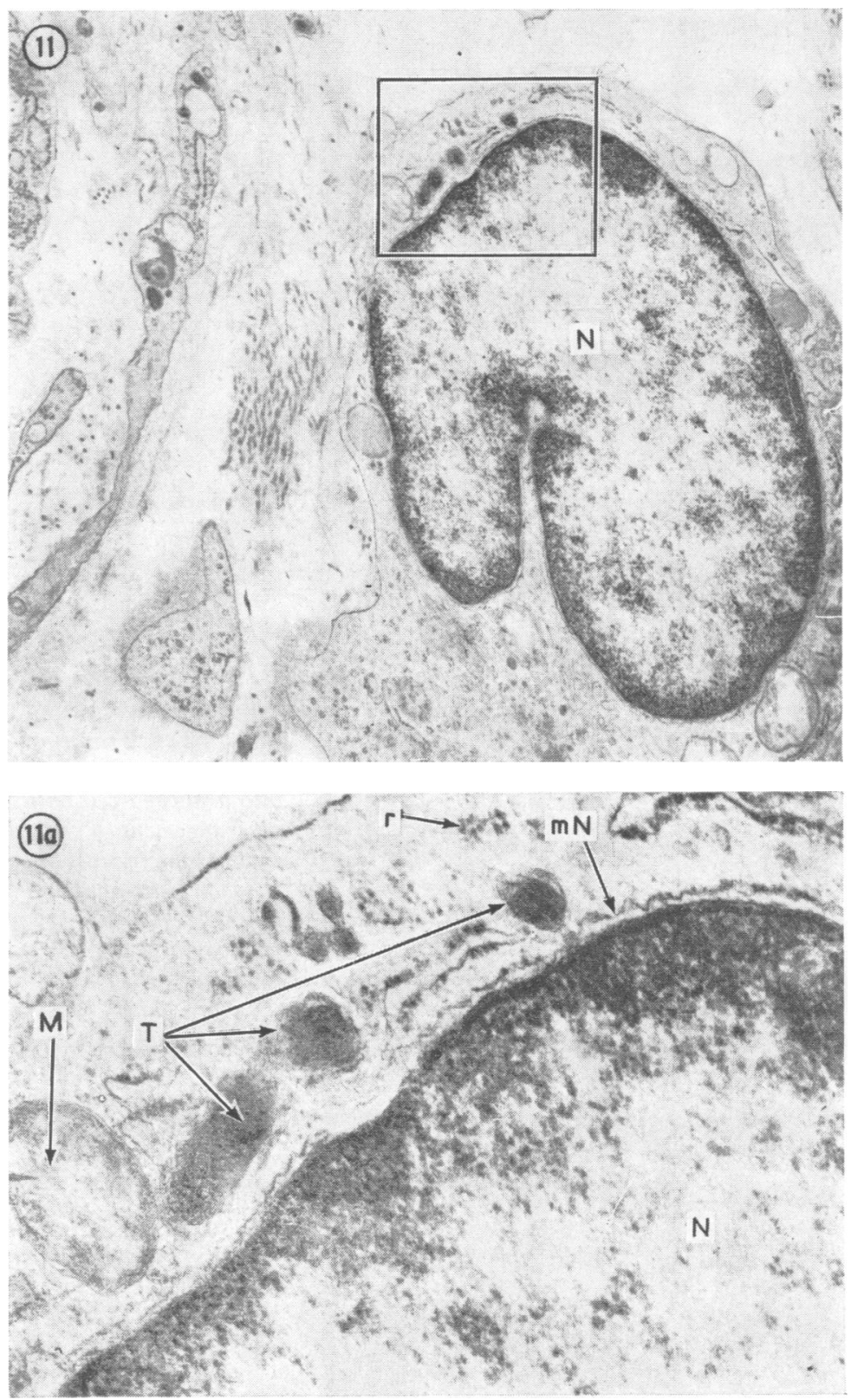

FIG. 11 Phagocytosis of Treponema pertenue by a monocyte. Ultrathin section of a yaws nodule of rabbit testicular membrane 2 months after infection $\times 12,000$

FIG. 11a The monocyte has a typical structure with characteristic nucleus $(N)$ and cytoplasm. The outer nuclear membrane $(m N)$ is scalloped. The zone of phagocytosis is represented by a narrow band of cytoplasm. The changed treponeme $(T)$ is partly lysed; $r$-ribosomes. The mitochondria $(M)$ are destroyed. $\times 45,000$ 


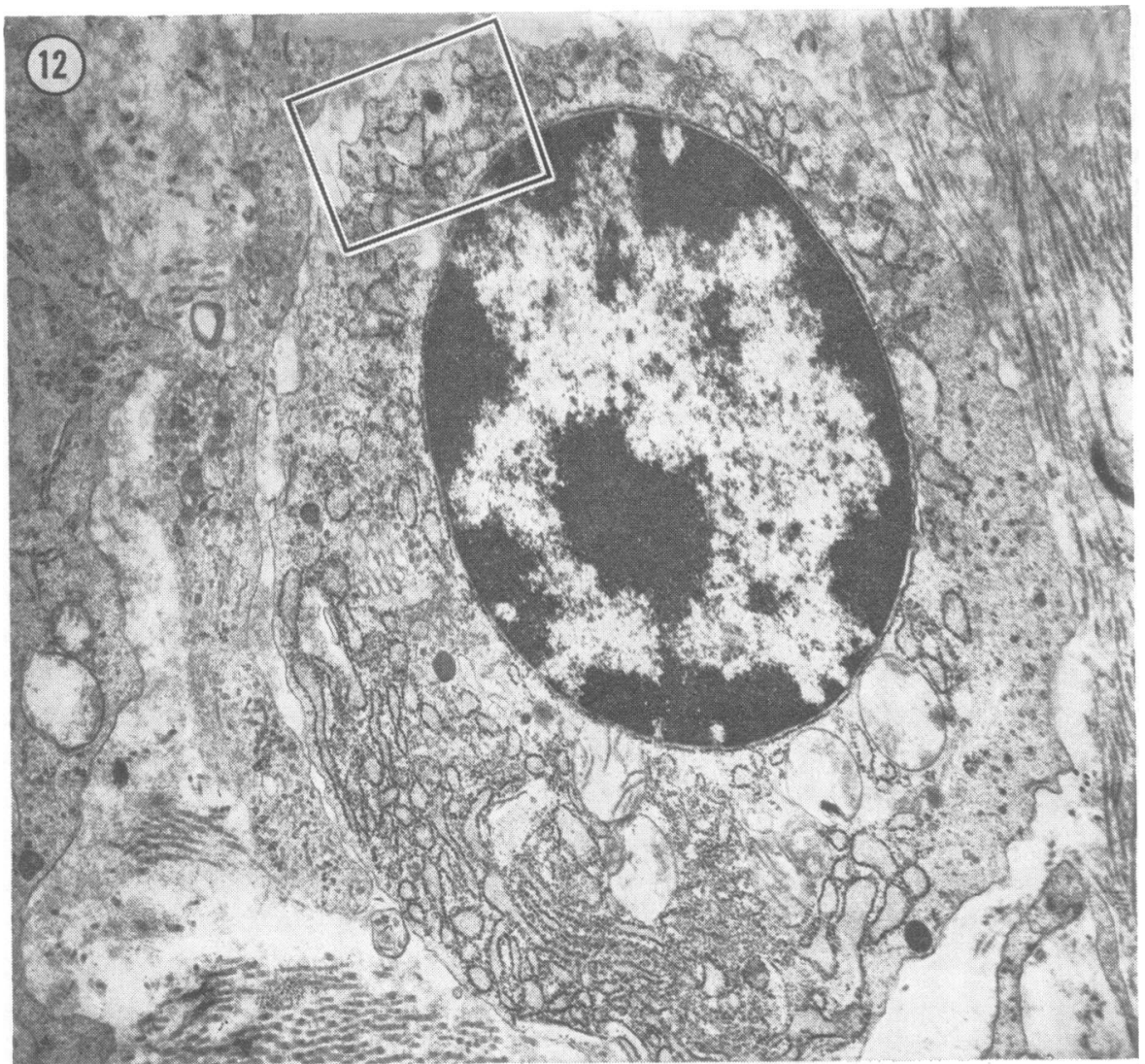

FIG. 12 Phagocytosis of Treponema pertenue by $a$ lymphocyte. Ultrathin section of a yaws nodule of rabbit testicular membrane 2 months after infection.

$\times 11,000$

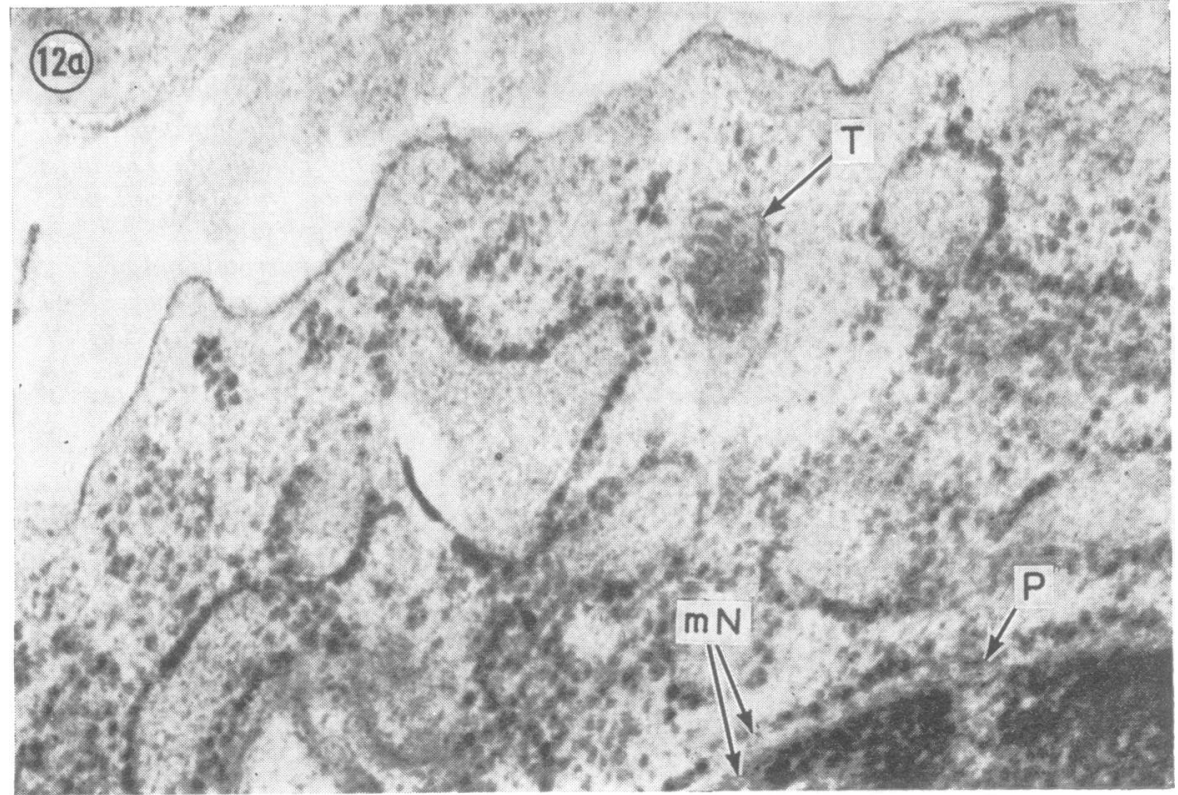

FIG. 12a Transition of a mesolymphocyte into a plasma cell with rearrangement of the endoplasmic reticulum characteristic of that process. The phagocytosis zone is of characteristic structure. The treponeme $(T)$ is isolated by a membrane from the cell cytoplasm and partially lysed; $m \mathrm{~N}$-nuclear membrane; $P$-pore. $\times 52,000$ 


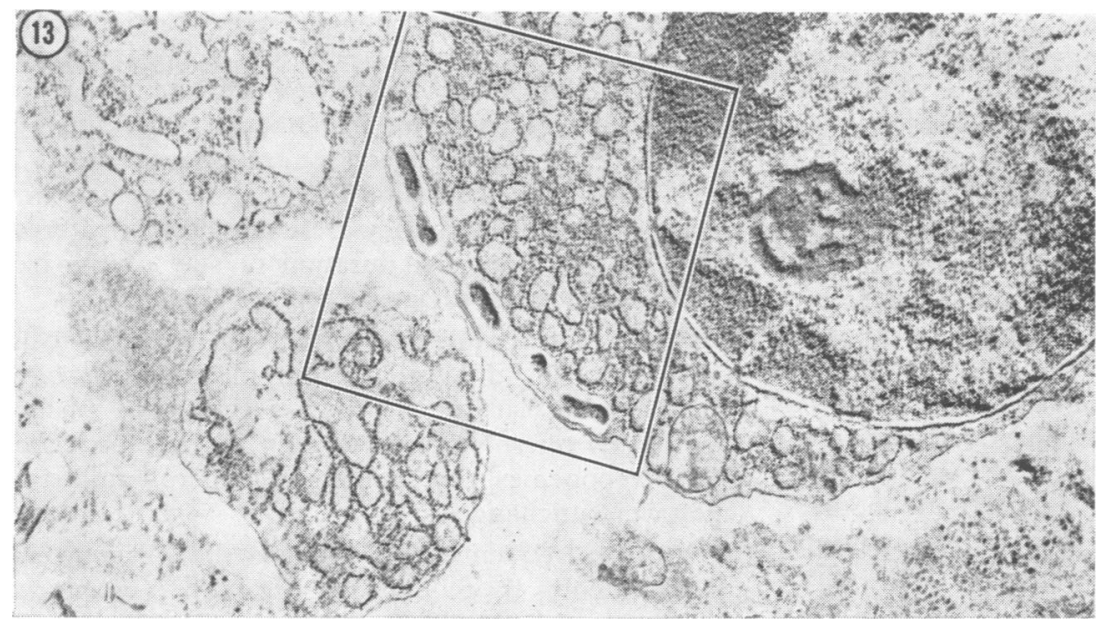

FIG. 13 Phagocytosis of Treponema pertenue by $a$ plasma cell. Ultrathin section of a yaws nodule of rabbit testicular membrane 2 months after infection. $\times 12,500$

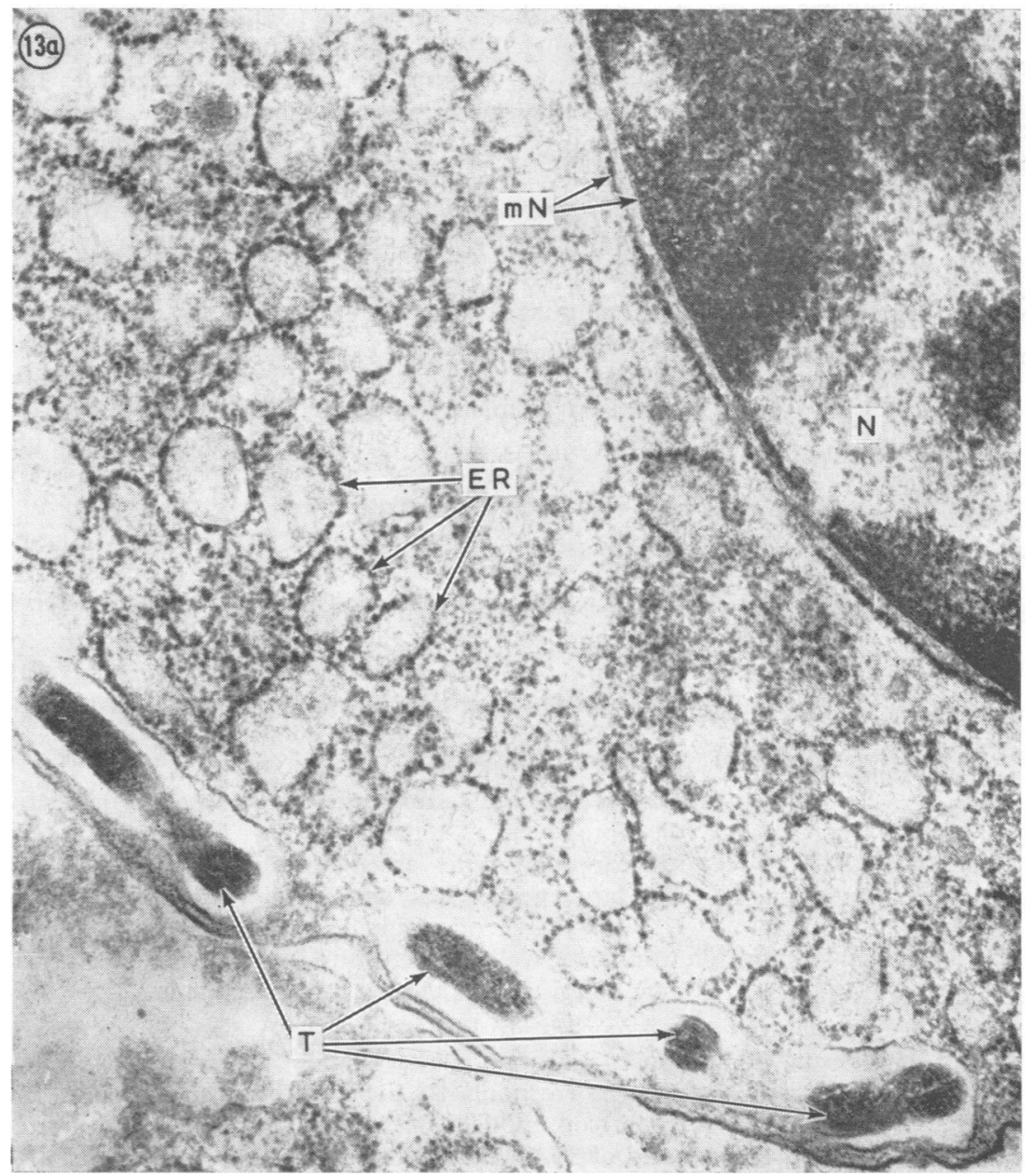

FIG. 13a Phagocytosed treponeme (T) has no cell wall. The fibrils are preserved. The walls of the long phagosomal canal, which is divided in the micrograph into three segments, are well-marked. $N$-nucleus; $m N$-nuclear membrane; ER-endoplasmic reticulum. $\times 22,000$ 
The term 'pinocytosis' is unsuitable in relation to treponemes, although from a physiological point of view it is a phenomenon of the same order as phagocytosis. The processes cannot be considered as identical mainly because pinocytosis is used for the trapping of liquid substances, whereas phagocytosis is used for the trapping of solids.

What is the explanation for the occurrence of invagination in some cases, and of encirclement and trapping by means of pseudopodia, etc., in others ? Are there any important differences between them?

It seems to us that the mode of absorption depends to a considerable extent on the phagocytosing cell, but there is no sharp boundary between them. Neutrophils mainly capture by means of pseudopodia, and macrophages, particularly after administration of penicillin, put out a huge number of long, thin pseudopodia. A long canal is later formed. In lymphocytes and plasma cells invagination predominates.

Phagocytic activity differs in different cells. Hertzog (1938) studied the phagocitic activity of various types of leucocyte and came to the following conclusions: neutrophils phagocytosed in 92 per cent. of cases; eosinophils in 84.8 per cent.; basophils not at all; lymphocytes in only 1.17 per cent. of cases; monocytes in 76 per cent. It is usually accepted that most cells do not carry out phagocytosis.

Cells can phagocytose both live and dead, virulent and non-virulent microbes. The fate of a phagocytosed micro-organism depends on whether it is captured alive or dead as well as on the cell which captures it.

Thus neutrophil leucocytes, which are rarely encountered in young chancres or orchitis, capture treponemes but, judging by the fact that no changes in the morphology of the phagocytosed treponemes can be seen in the micrographs, it may be assumed that incomplete phagocytosis-'endocytobiosis'takes place in these cells.

Mečnikov pointed out that the causal agents of anthrax, swine erysipelas, and tuberculosis multiplied inside the phagocytes that had swallowed them and could cause infection and illness if administered to animals.

Bronštejn (1922) demonstrated 'endocytobiosis' in regard to gonococci and this was experimentally confirmed by Ovčinnikov, Bohonek, and Litvak (1934).

When treponemes multiply inside a neutrophil, the cell perishes. The freed treponemes are qualitatively quite different, it seems, from treponemes which have not been phagocytosed. As a result of phagocytosis they have been exposed to various hydrolytic enzymes contained in the granules and their treponemal activity has been reduced. In repeat phagocytosis of these treponemes, the reaction of the cells and the treponemes is different again. It appears that the neutrophils digest well treponemes which have been weakened, for instance by penicillin, but do not destroy unchanged live treponemes. That is why in some neutrophilis the treponemes are well lysed, while in others they are completely unaltered. Possibly, however, the duration of stay of the treponeme inside the phagosome plays a part.

While neutrophils participate in phagocytosis, particularly in the later stages of existence of a chancre, we hardly ever saw treponemes phagocytosed by microlymphocytes. On the rare occasions when treponemes were seen inside a microlymphocyte they were unchanged.

A more frequent observation is the phagocytosis of treponemes by monocytes (Fig. 11). A monocyte is considerably larger than a microlymphocyte. It has a horseshoe-shaped nucleus, placed eccentrically. In the nucleus chromatin is not abundant but is gathered in clumps round the periphery. The nuclear membranes are well marked. The ribosomal apparatus is poorly developed. There are a considerable number of vacuoles, vesicles, and granules. The Golgi apparatus is represented by single vesicles. The mitochondria are half destroyed. The treponeme phagocytosed by the monocyte is partly lysed.

The phagocytosis of Treponema pallidum and Treponema pertenue by plasma cells is of great interest. The plasma cells are particularly interesting because it is mainly in them that antibody formation takes place (Nossal', 1966). Radioautography has clearly established that the bulk of gamma-globulin is elaborated in the plasma cells.

The use of fluorescent antibodies and ferritinbound antibodies has established that gammaglobulin and antibodies are localized in these cells.

Plasma cells have the characteristic structure of secretory cells: there is a typical endoplasmic reticulum with numerous ribosomes, as well as a nucleus of characteristic structure with inner and outer nuclear membranes.

There is an abundance of nuclear chromatin distributed in a stellate pattern. The pores in the nuclear membranes are distinctly marked and there is a large perinuclear space. The phagocytosis zone is usually free of organelles. There are a moderate number of well-marked mitochondria and lysosomes. The Golgi zone is clearly distinguishable.

According to Robertson (1959), the cell membrane consists of two darker bands of roughly $20 \AA$ and these correspond to the two protein layers of the Robertson model. Between them there is a lighter band of $35 \AA$, corresponding to the lipoid layer. 
As a rule $T$. pallidum and $T$. pertenue keep their clear-cut morphological structure in the plasma cell, together with all the features characteristic of treponemes (Figs 5, 7, 10, and 13). The impression is gained that treponemes inside plasma cells undergo little or no change.

In the cytoplasmic part of the outer nuclear membrane there are numerous ribosomes.

In addition, the treponeme is usually contained in what appears to be a casing. It must be assumed that this is elaborated by the cell and not by the treponeme.

It is only occasionally that treponemes are visible in a plasma cell without a casing and with all their structural features intact, but some have undergone partial change. In some cases treponemes inside the phagosomal canal of a plasma cell lack an outer wall. They undergo some changes, which appear to be the beginning of lysis. The fact that in some cases treponemes are well isolated and unchanged, while in others they have no outer wall and have begun to be lysed can be ascribed to the different degrees of maturity of the plasma cells and their differing levels of activity. It must be assumed that antibody formation also differs in these cells. It is considered that, in the presence of antigen, the development of the endoplasmic reticulum is stimulated, as a result of which the nucleus is displaced into a corner of the cell. It must be noted, however, that even without antigen the endoplasmic reticulum is well marked in some cells. It may be assumed with the same degree of probability that this depends on the degree of maturity of the cell. The assumption is not yet proved. It should be noted that the overwhelming majority of cellular forms in hard-chancre tissue have an endoplasmic reticulum with a secretory type of structure.

In plasma cells, and particularly in the long-lived lymphocytes, encapsulated treponemes may be preserved for a long period and may be carried into distant organs and tissues which are difficult of access for antibiotics and antibodies, while antibody formation in these cells may continue for as long as the antigen continues to act as an irritant.

The fact that cells can again enter the blood stream and be carried into remote organs is well illustrated by Fig. 14 (detail 14b), in which a treponeme ( $T$ ) is clearly visible in a blood vessel near a long intracellular space (lymph sinus), connected with a cavity full of lymph. In the intracellular space there are a large number of treponemes which are possibly entering the blood stream through these lymph gaps. The treponeme in an endothelial cell $\left(T^{\prime \prime}\right)$ (Fig. 14a) is isolated by three layers of membrane and, as it were, encapsulated. It must be assumed that a treponeme of this sort is better protected against external factors than the extracellular treponemes. The treponeme itself lacks an outer wall, but no other changes can be seen.

When the cells are destroyed once lysis has affected their whole structure, treponemes surrounded by a double membrane may be released and exist extracellularly. Figs 15 and 15a show fragments of a cell which has been affected in its entirety by lysis. The mitochondria are at the stage of disruption, but in some of them the cristae on the periphery are intact. In others there is only the external membrane and the cristae have already gone. In Fig. 15 the longitudinally-sectioned and cross-sectioned Treponema pertenue are apparently one and the same organism cut in different planes. The cross-sectioned portion (Fig. 15a) seems to be already outside the cell, whereas the longitudinally-sectioned part is still linked in some way with the cell as it undergoes lysis.

As the cell is further lysed the treponemes surrounded by the walls of the phagosomal canal, which gives the impression of a casing, will already be outside the cell.

We have already noted that, in most cases, a treponeme in a plasma cell lies along the cell's outer membrane. The question of the communication of plasma cells with antibody formation and the survival of treponemes in the course of an illness requires separate study.

Macrophages are characterized by a large irregularly-shaped nucleus with a narrow marginal band of chromatin. The nuclear membrane consists of the three-layered nuclear membrane proper and a three-layered outer nuclear membrane. The nuclear pores are few in number. In the cytoplasm there is a scanty endoplasmic reticulum of the granular type with a large number of free ribosomes and a Golgi apparatus with small structural elements.

The moderate numbers of mitochondria are of small size and typical structure. Lysosomes are of various types: enzymatic granules, myeloid bodies, lipid granules, and residual bodies. The macrophage is covered with a plasma membrane consisting of two electron dense sheets with a diameter of $25 \AA$ each, separated by a layer of medium electron density and a diameter of about $30 \AA$. The cortical layer of the macrophages and also the pseudopodia are almost free of organelles and endoplasmic reticulum and are represented by a homogeneous or finely granular hyaloplasm. The structure of the macrophages may change in relation to the activity of the cellular processes. 

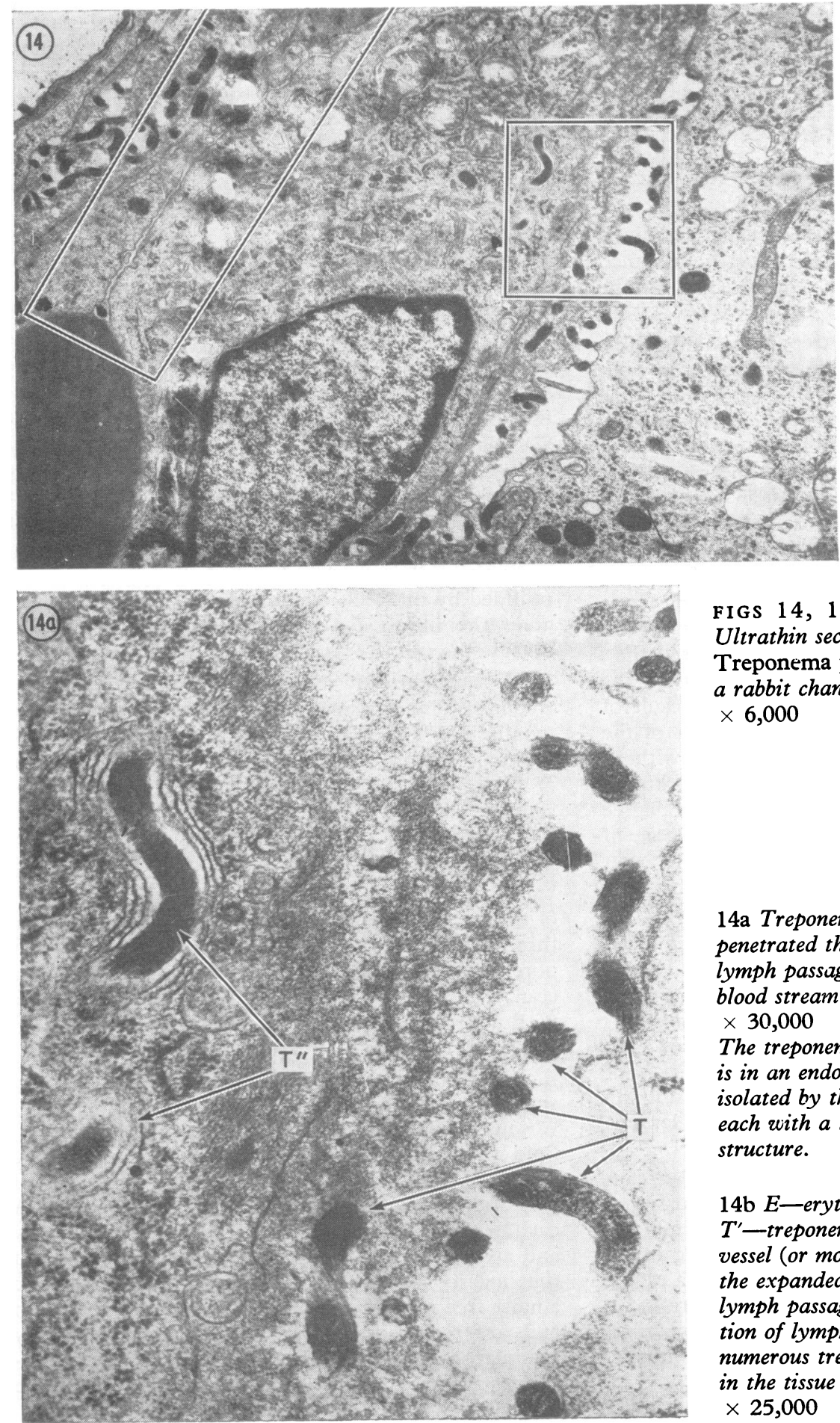

FIGS $14,14 \mathrm{a}$, and $14 \mathrm{~b}$ Ultrathin section of Treponema pallidum from a rabbit chancre.

$\times 6,000$

14a Treponemes ( $T$ ) have penetrated through the lymph passages into the blood stream.

$\times 30,000$

The treponeme $\left(T^{\prime \prime}\right)(14 \mathrm{a})$ is in an endothslial cell isolated by three membranes, each with a three-layered structure.

14b E-erythrocyte. $T^{\prime}$-treponeme inside a vessel (or more precisely in the expanded entrance to a lymph passage). Aggregation of lymph (L.y) and numerous treponemes $(T)$ in the tissue spaces. $\times 25,000$ 


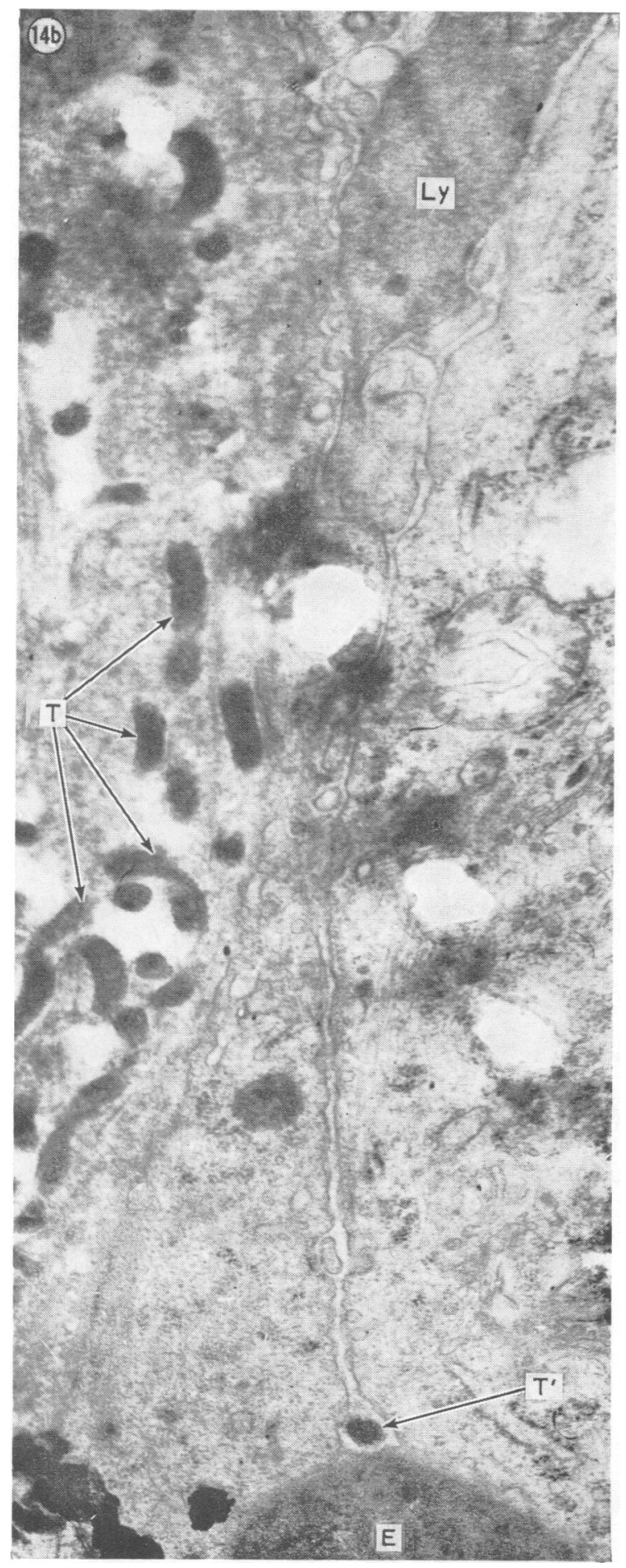

In the macrophages-primarily histiocytes-the treponemes are similar in structure to those inside the plasma cells. One of them is in a phagosomal canal which acts as a casing and has preserved its structural features (Fig. 16), while others are in a very long phagosomal canal and stretch deep into the cell. They also have undergone no visible changes or else only part of the treponeme has been affected by change.

Fig. 17 shows a treponeme in a long phagosomal canal. In the sector where there is a cross-sectioned treponeme it is easy to see the two layers of the outer wall, the cytoplasmic membrane, and the obliquelysectioned fibrils. Part of the longitudinally-sectioned treponeme (it must be assumed that it is the same as the one in cross-section) is partly lysed. As a result of its length, the changes in a treponeme may differ in different sectors. They are greater in places where the phagosome fuses with the lysosome. Treponemes situated in the cytoplasm itself have lost their outer walls and are in the initial stage of lysis. Finally, treponemes inside the phagosome which have apparently fused with the lysosomes have lost their structure (Fig. 18).

The mitochondria, which are greatly affected in these cells, also play some role in these processes. In Fig. 19 a still unchanged Treponemu pertenue is still clearly visible inside a phagosome, with which it has fused. A residual body is also present. The longitudinally-sectioned treponeme is in the hyaloplasm itself; it has lost its outer wall but so far no other changes can be seen.

The last type of cell we shall deal with is the fibroblast, which has a very characteristic structure (Fig. 20). The cytoplasmic membrane of the fibroblast forms numerous pinocytotic vesicles, which indicates the intense metabolism occurring inside the cell.

Its nucleus is large and stretched out along the long diameter of the cell. It is comparatively poor in chromatin, which forms a small band on the periphery. The nuclear membrane is of typical structure but the perinuclear space is not visible. The endoplasmic reticulum is scanty. The hyaloplasm contains a considerable number of ribosomes. The number of mitochondria and lysosomes is not large and the Golgi apparatus is not very distinct. The plasma membrane is usually three-layered. The cell processes are elongated.

The treponemes penetrate inside the fibroblast as a result of shallow invaginations in the peripheral zones of the processes, followed by encapsulation. Inside the fibroblasts the treponemes preserve their morphological features (Fig. 20a). The membrane $(\mathrm{m})$, phagosomes $(\mathrm{PH})$, and treponemes can be seen clearly inside it. 


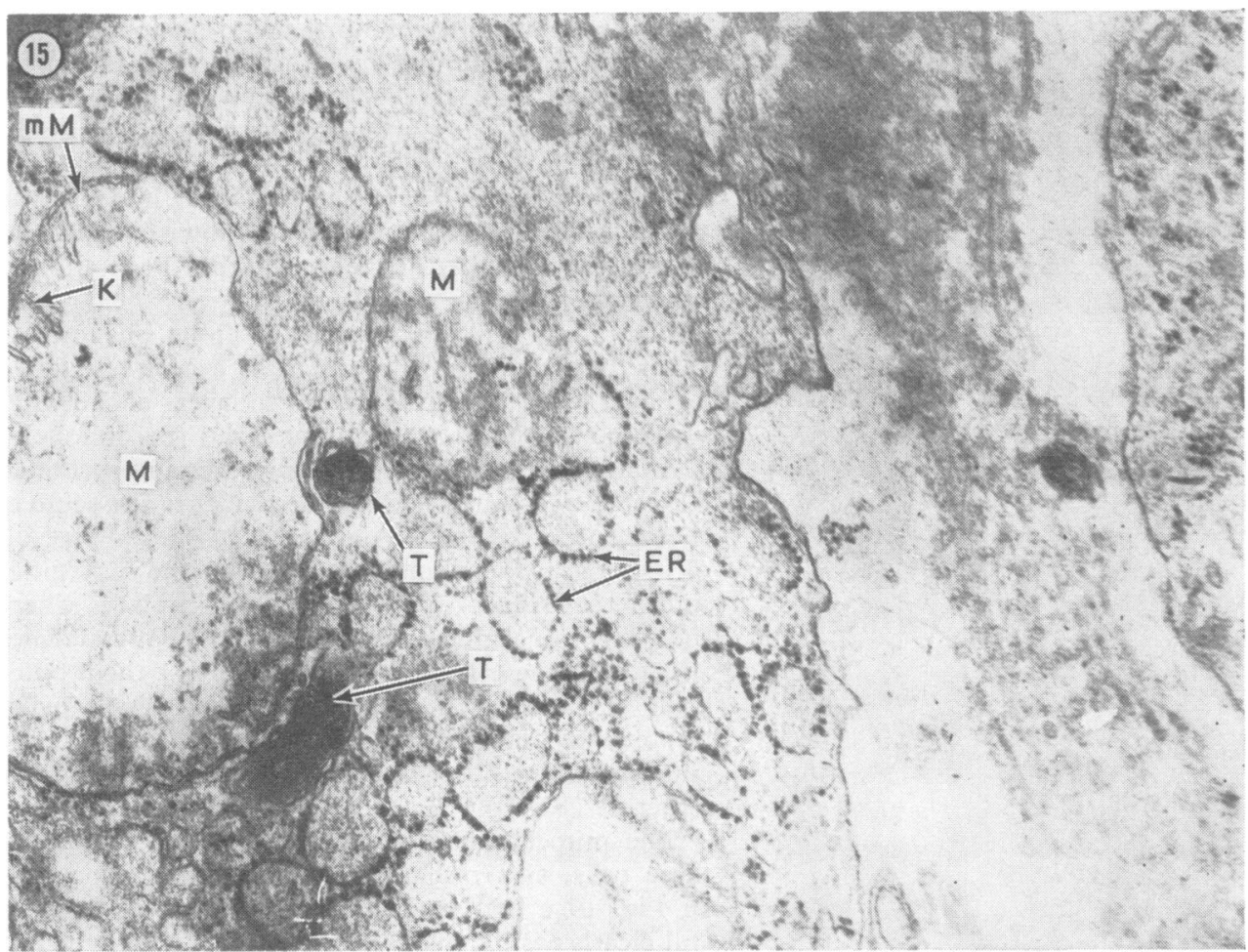

I G S 15 and 15a Phagocytosis of Treponema pertenue by $a$ plasma cell. Ultrathin section of a yaws nodule of rabbit testicular membrane 2 months after infection.

Fragments of a plasma cell in the stage of lysis which affects the whole cell. In the mitochondria $(M)$, the outer membrane ( $m M$ ) and cristae $(K)$ have only been partially preserved. $\times 30,000$

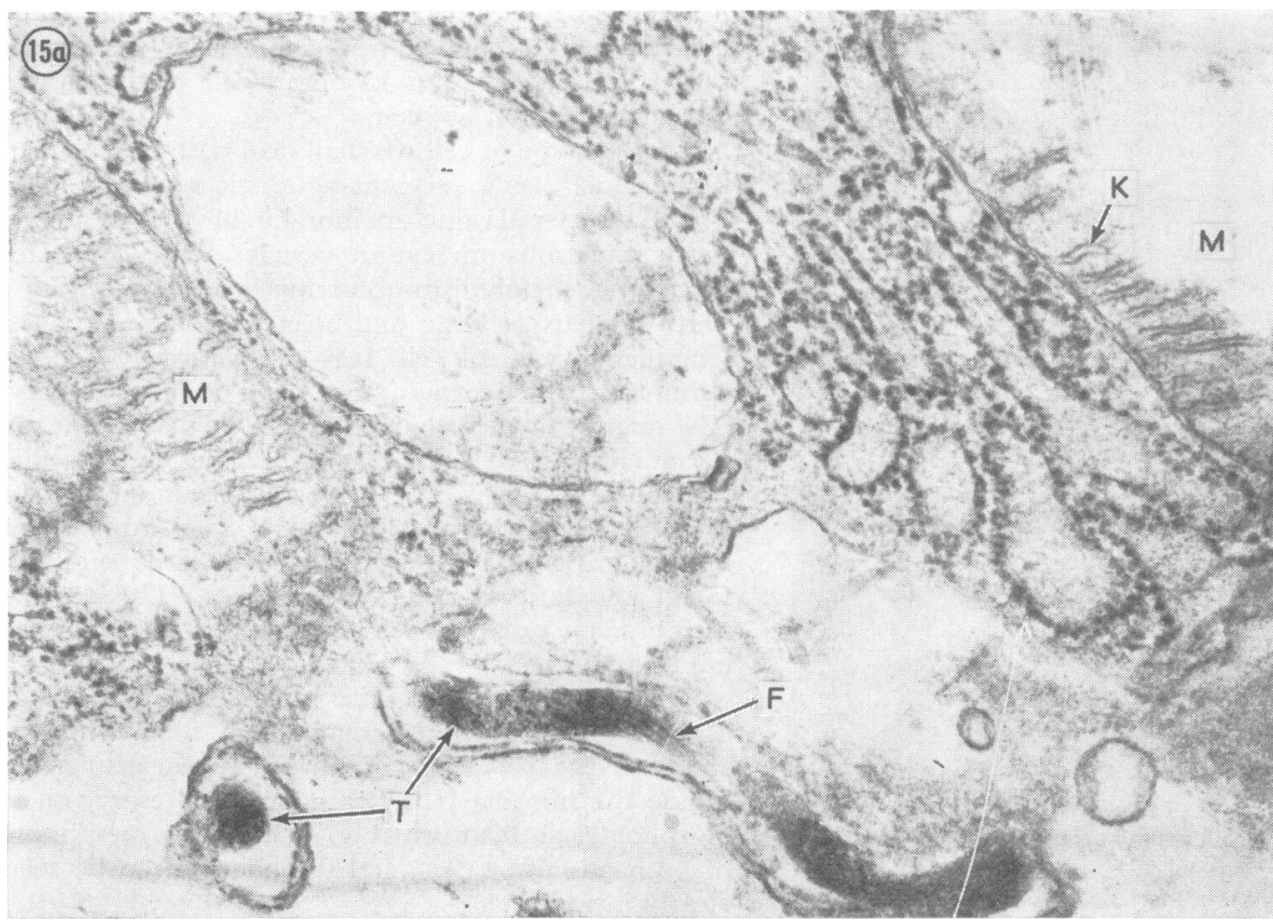

In Fig. 15a the treponeme (T) shown in Fig. 15 (cross-sectioned) is not changed. Formerly within the cell, it gives the impression of being outside the cell or connected only with remnants of the cytoplasm (longitudinal section). It is surrounded by $a$ casing and the fibrils are preserved $(F)$. ER-Endoplasmic reticulum.

$\times 30,000$ 


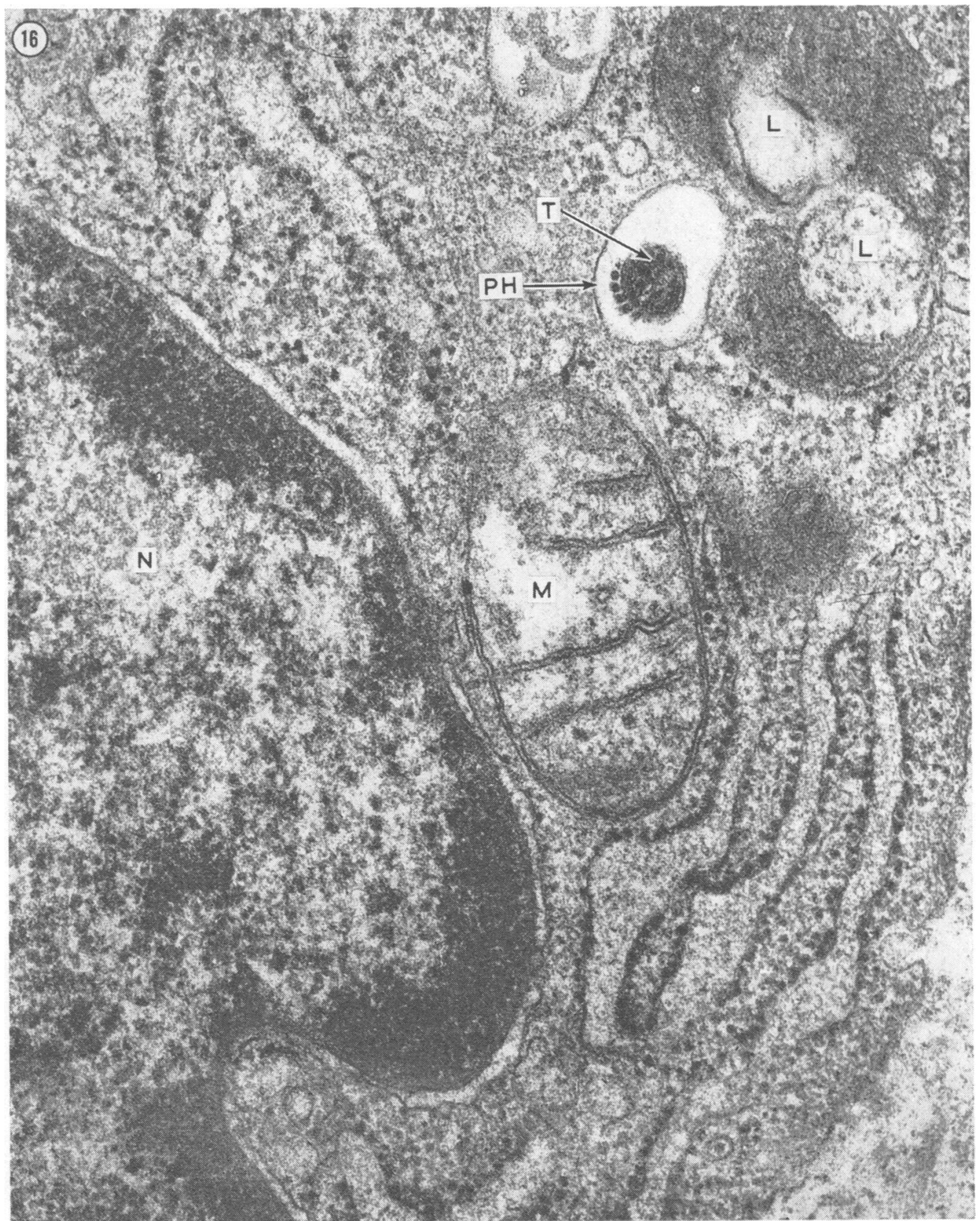

FIG. 16 Phagocytosis of Treponema pallidum by a macrophage. Ultrathin section of rabbit hard-chancre tissue 47 days after infection. The macrophage fragment shown illustrates the formation of a phagolysosome. A phagosome $(P H)$ containing Treponema pallidum $(T)$ forms a common membrane wall with a lysosome $(L)$. The mitochondria $(M)$ are clearcut and the endoplasmic reticulum is well marked. $N-$ nucleus. $\quad \times 60,000$ 


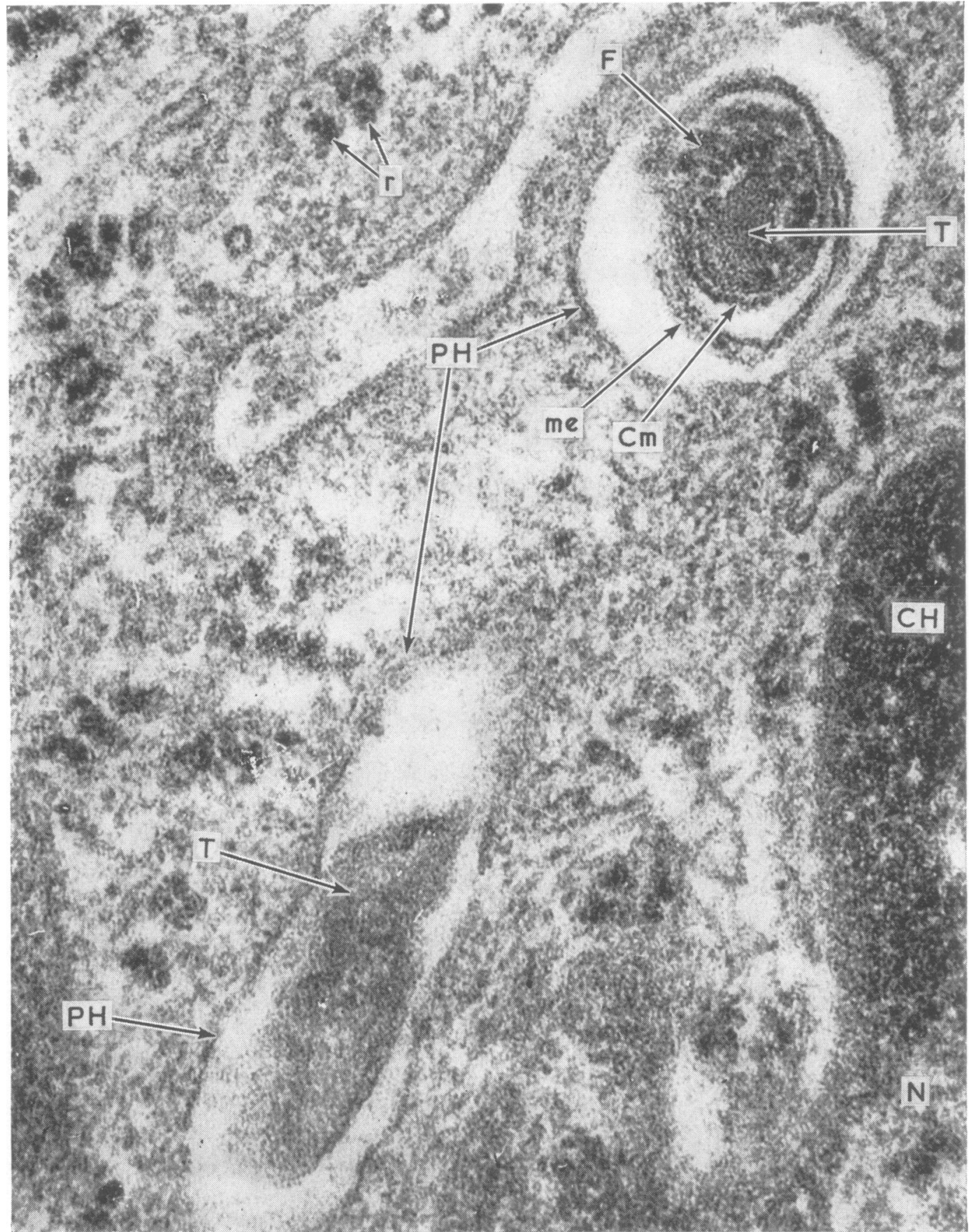

FIG. 17 Phagocytosis by a macrophage. Ultrathin section of rabbit hard-chancre tissue. The treponeme $(T)$ is in a long phagosomal canal $(P H)$ with clearly marked walls. The two layers of the outer wall (me), the cytoplasmic membrane $(\mathrm{Cm})$, and a fibrillar bundle $(F)$ are clearly visible in the cross-sectioned treponeme. $N$-nucleus; r-ribosomes; CH-chromatin. $\quad \times 105,000$ 


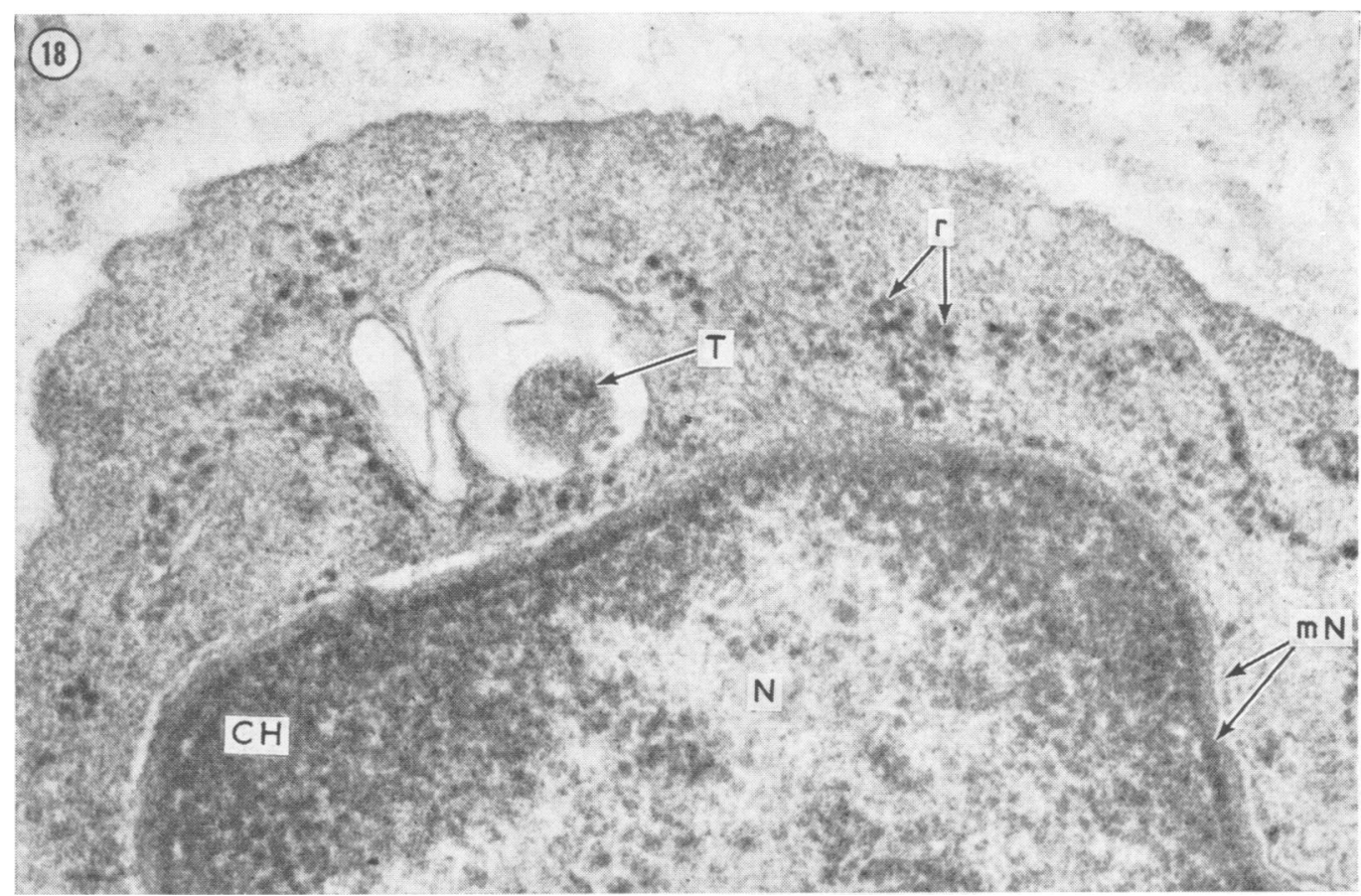

FIG. 18 Phagocytosis of Treponema pertenue by a mesolymphocyte. Ultrathin section of a yaws nodule in rabbit testicular membrane. The treponeme $(T)$ inside the lysosome is in process of being digested. $N$-nucleus; $\mathrm{CH}$-chromatin; $\mathrm{m} N$-nuclear membranes; $r$-ribosomes. $\quad \times 38,000$

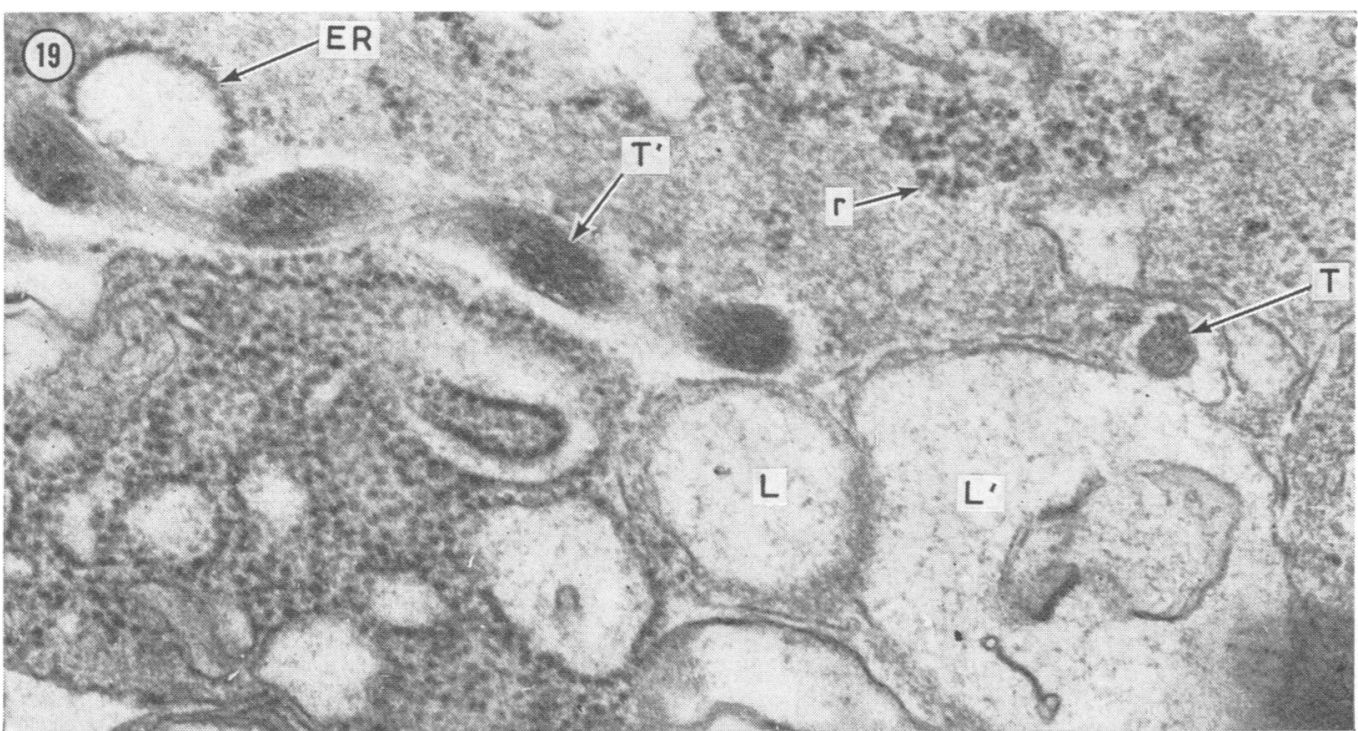

FIG. 19 Phagocytosis of Treponema pertenue. Fusion of lysosomes. A cross-sectioned treponeme $(T)$ is inside a lysosome. A longitudinally-sectioned treponeme $\left(T^{\prime}\right)$ lies in the cytoplasm itself. Except for the absence of outer walls its structure is unchanged. There are a lysosome $(L)$, a lysosome with a residual body $\left(L^{\prime}\right)$, cisternae of endoplasmic reticulum $(E R)$, and ribosomes $(r) . \quad \times 30,000$ 


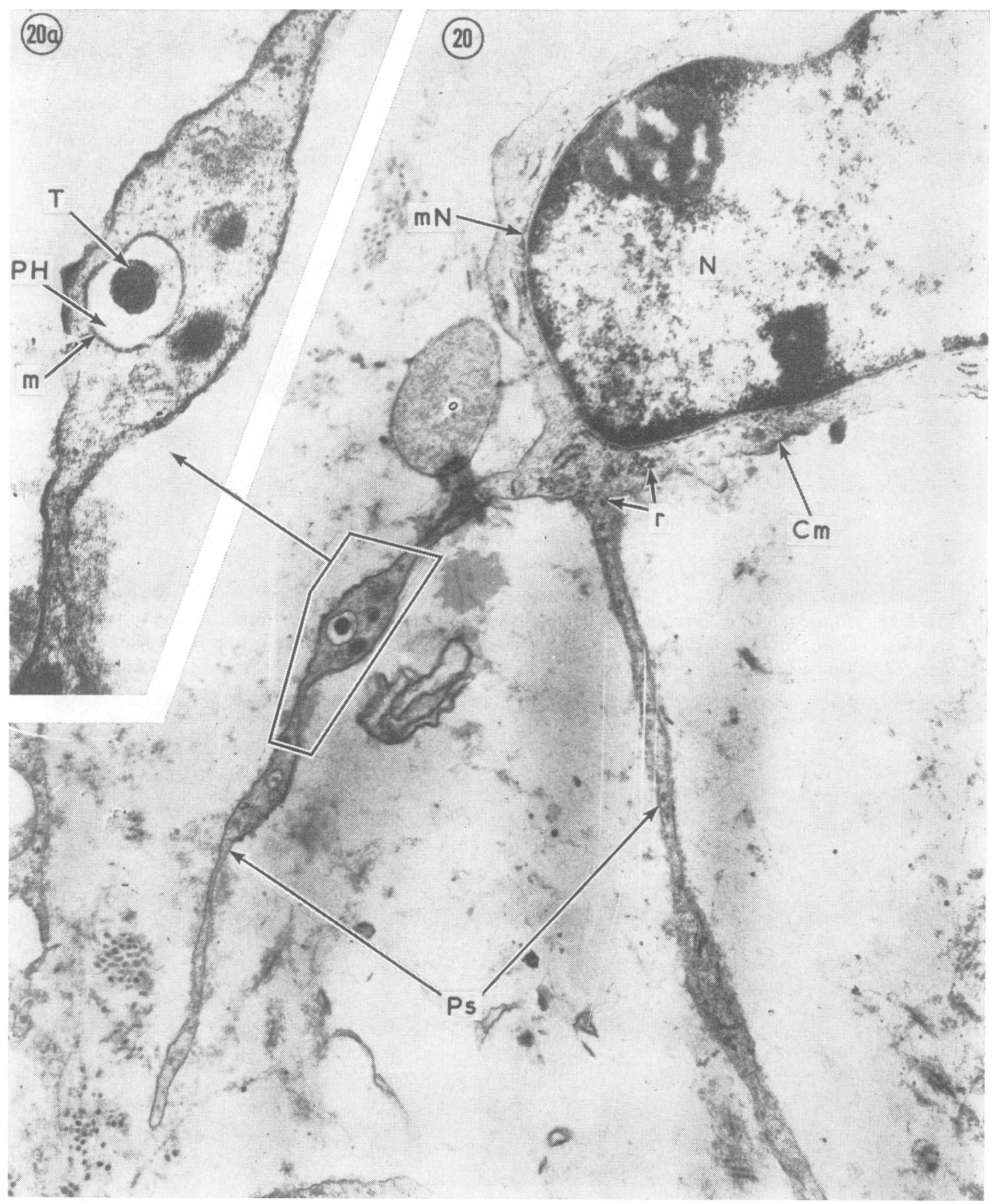

FIG. 20 Phagocytosis of Treponema pertenue by a fibroblast. Ultrathin section of a yaws nodule in rabbit testicular membrane 2 months after infection. $\times 12,500$

FIG. 20a The treponeme (T) inside the phagosome (PH) is little changed. Ps-pseudopodia; $m$-cell membrane; $N$-nucleus; $m N$-nuclear membrane; $C m$-cytoplasmic membrane; $r$-ribosomes. $\quad \times 32,000$ 
If a comparison is made between the pattern of phagocytosis of Treponema pallidum in early chancres and during chancre resorption, particularly in the course of treatment, it will be noted that in the first case the micro-organisms have a more clear-cut structure and have undergone fewer changes. The number of cells containing phagocytosed treponemes is small. All this bears witness to their activity.

In the second case there are many treponemes undergoing lysis inside the cells, as well as treponemes with clear-cut morphology. This indicates the presence not only of live treponemes but also apparently of weakened treponemes which are being lysed as a result of phagocytosis. After the administration of penicillin the number of cells with phagocytosed treponemes is considerably greater.

\section{Conclusions}

(1) The predominant type of phagocytosis at the beginning of the illness in syphilis and yaws is incomplete. When a chancre is resorbed, particularly during treatment, intracellular lysis of the treponemes -complete phagocytosis-is predominant.

(2) There is no sharp boundary between incomplete and complete phagocytosis except in the late stages, when the process of lysis is clearly marked.

(3) The chief part in phagocytosis in cases of syphilis and yaws is played by macrophages, followed (in order) by plasma cells, fibroblasts, neutrophils (in the late stages), and lymphocytes (to a small extent). In our investigations we did not see phagocytosis by eosinophils or mast cells. No difference was found between syphilis and yaws in respect of phagocytosis. (4) In the process of chancre resorption during treatment, macrophages play the most important part in phagocytosis.

(5) It is not improbable that in plasma cells the treponeme is protected by a membrane elaborated by the cell; because of its functional features it produces antibodies and by being transported into remote organs may to some extent lead to persistence of the infection.

\section{Summary}

In view of the great importance of phagocytosis in the control of infection, the phenomenon was studied under the electron microscope in rabbit tissue syphilomas and in foci of infection in yaws at different dates after infection.

The methods used have been described in previous papers.

No difference was found between phagocytosis in syphilis and in yaws. In the initial stage of syphilis incomplete phagocytosis predominates in rabbit chancre tissue but, when the chancre is being resorbed, particularly during penicillin treatment, complete phagocytosis is predominant.

The main participants in phagocytosis in syphilis and yaws are macrophages, followed by plasma cells, fibroblasts, neutrophils, and lymphocytes.

In plasma cells treponemes are quite often protected by membranes, apparently elaborated by the cell itself. Because of the special features of cell function, the cell produces antibodies and their transportation to remote organs may lead to persistence of the infection.

The process of capture of the treponemes does not differ substantially from that in other infections. The treponeme is seen to approach the phagocytosing cell and is then attracted, absorbed, and digested or isolated. The cell may also put out pseudopodia and use them to draw the treponeme inside itself. The process of capture, the nature of phagocytosis, and the subsequent fate of the treponeme depends on the type of phagocytosing cell and the condition of the treponeme.

\section{References}

Ado, A. D. (1961) 'Patofiziologija fagocitov' (The pathological physiology of phagocytes). Medgiz, Moscow

BronštejN, O. I. (1922) 'E̊ndocitobioz gonokokka' (Gonococcal endocytobiosis) In 'Sbornik trudov professorov i prepodavatelej medicinskogo Fakulteta Irkutskogo Universiteta' (Collection of papers by the professors and other teaching staff of Irkutsk University Medical Faculty), p. 41

EhrmanN, S. (1906) Wien. klin. Wschr., 19, 828

GIERKE, E. (1906) Münch. med. Wschr., 53, 393 (1907) Zbl. Bakt., Abt. 1 (Orig.), 44, 348

Hertzog, A. J. (1938) Amer. F. Path., 14, 595

Levaditi, C. (1906) Ann. Inst. Pasteur, 20, 924

$\longrightarrow$, and Roche, J. (1907) C. R. Soc. Biol. (Paris), 62, 619,815

MEČNIKov, I. I. (1884) Berl. klin. Wschr., 21, 808, 818

- (1923) 'Lekcii po sravnitel'noj patologii vospalenija' (Lectures on the Comparative Pathology of Inflammation). 'Giz', 37-77

- (1951) 'Učenic o fagocitoze i ego e̊ksperimental'nye osnovy' (The theory of phagocytosis and its experimental basis) In 'Voprosy immuniteta. Izbrannye trudy' (Questions of immunity. Selected works). Publishing House of the Academy of Sciences of the USSR

NossaL', D. (1966) 'How cells produce antibodies', In 'Molekuly i kletki' (Molecules and cells). Translations from English, ed. G. M. Frank. 'Mir' Publishing House, Moscow

Ovčinnikov, N. M., Bohonek, A.A., and Litvak, R. V. (1934) Urologiya, No. 1, p. 84 
— and Delektorskij, V. V. (1969) WHO/VDT/RES/69, 184

(1970) Bull. Wld Hlth Org., 42, 437

ROBERTSON, J. D. (1959) In 'The Structure and Function of Subcellular Components', pp. 3-43. Biochemical Society Symposia, No. 16. University Press, Cambridge

TURNER, T. B., and Hollander, D. H. (1957) 'Biology of the Treponematoses'. World Health Organization, Monograph Series No. 35. WHO, Geneva

\section{KEY}

\begin{tabular}{|c|c|}
\hline $\begin{array}{l}\text { CH } \\
\text { Cm } \\
\text { EC } \\
\text { E } \\
\text { ER } \\
\text { F } \\
F^{\prime} \\
\text { K } \\
\text { L } \\
L^{\prime} \\
\text { Ly } \\
\text { M } \\
\text { m } \\
\text { me } \\
\text { mM } \\
\text { mN } \\
\text { N } \\
\text { P } \\
\text { PH } \\
\text { Ps } \\
\text { r } \\
\text { T } \\
T^{\prime} \\
T^{\prime \prime} \\
\text { V }\end{array}$ & $\begin{array}{l}\text { chromatin } \\
\text { cytoplasmic membrane } \\
\text { ectoplasm } \\
\text { erythrocyte } \\
\text { endoplasmic reticulum } \\
\text { superficial fibril } \\
\text { deep-lying fibril } \\
\text { cristae } \\
\text { lysosome } \\
\text { lysosome with residual body } \\
\text { lymph } \\
\text { mitochondria } \\
\text { cell membrane } \\
\text { two layers of outer wall of treponeme } \\
\text { outer membrane } \\
\text { nuclear membrane } \\
\text { nucleus } \\
\text { pore } \\
\text { phagosome } \\
\text { pseudopodia } \\
\text { ribosome } \\
\text { cross-section treponeme } \\
\text { longitudinal-section treponeme } \\
\text { treponema in an endothelial cell } \\
\text { vacuole }\end{array}$ \\
\hline
\end{tabular}

Étude au microscope électronique de la phagocytose dans la syphilis et le pian

\section{SOMMAIRE}

Considérant la grande importance de la phagocytose dans la lutte contre l'infection, ce phénomène fut étudié au microscope électronique dans les tissus de syphilomes chez le lapin et dans des foyers d'infection pianique, à différentes étapes après le début de l'infection.

Les méthodes employées ont été décrites dans des articles antérieurs.

Il ne fut pas trouvé de différence pour la phagocytose entre la syphilis et le pian. Au stade initial de la syphilis, c'est la phagocytose incomplète qui prédomine dans les tissus du chancre chez le lapin, mais quand le chancre est en voie de disparition, particulièrement au cours du traitement par la pénicilline, la phagocytose complète prédomine.

Dans la syphilis et le pian, ce sont les macrophages qui participent principalement à la phagocytose, suivis par les plasmocytes, les fibroblastes, les neutrophiles et les lymphocytes.

Dans les plasmocytes, les tréponèmes sont très souvent protégés par des membranes apparemment produites par la cellule elle-même. À cause des caractéristiques spéciales de la fonction cellulaire, la cellule produit des anticorps et leur transport à des organes éloignés peut entraîner la persistance de l'infection.

Le processus de capture des tréponèmes ne diffère guère de ce que l'on observe dans d'autres infections. On voit le tréponème se rapprocher de la cellule phagocytaire et être alors attiré, absorbé et digéré ou isolé. $\mathrm{La}$ cellule peut aussi produire des pseudopodes et s'en servir pour capturer le tréponème. Le processus de capture, la nature de la phagocytose et le sort ultérieur du tréponème dépendent du type de la cellule phagocytaire et de l'état des tréponèmes. 